Louisiana State University

LSU Digital Commons

Faculty Publications

Department of Biological Sciences

$9-1-2005$

\title{
Status, trends and management of sturgeon and paddlefish fisheries
}

\author{
Ellen K. Pikitch \\ Pew Institute for Ocean Science \\ Phaedra Doukakis \\ Pew Institute for Ocean Science \\ Liz Lauck \\ Wildlife Conservation Society \\ Prosanta Chakrabarty \\ University of Michigan, Ann Arbor \\ Daniel L. Erickson \\ Wildlife Conservation Society
}

Follow this and additional works at: https://digitalcommons.Isu.edu/biosci_pubs

\section{Recommended Citation}

Pikitch, E., Doukakis, P., Lauck, L., Chakrabarty, P., \& Erickson, D. (2005). Status, trends and management of sturgeon and paddlefish fisheries. Fish and Fisheries, 6 (3), 233-265. https://doi.org/10.1111/ j.1467-2979.2005.00190.x

This Article is brought to you for free and open access by the Department of Biological Sciences at LSU Digital Commons. It has been accepted for inclusion in Faculty Publications by an authorized administrator of LSU Digital Commons. For more information, please contact ir@lsu.edu. 


\title{
Status, trends and management of sturgeon and paddlefish fisheries
}

\author{
Ellen K Pikitch ${ }^{1,2 *}$, Phaedra Doukakis ${ }^{1,2 *}$, Liz Lauck ${ }^{3}$, Prosanta Chakrabarty ${ }^{4}$ \& Daniel L Erickson ${ }^{3}$ \\ ${ }^{1}$ Pew Institute for Ocean Science, 126 East 56th Street, Mezzanine, New York, NY 10022; ${ }^{2}$ University of Miami, Rosenstiel \\ School of Marine and Atmospheric Science, 4600 Rickenbacker Causeway, Key Biscayne, FL 33149-1098; \\ ${ }^{3}$ Marine Conservation Program, Wildlife Conservation Society, 2300 Southern Blvd., Bronx, NY 10460; \\ ${ }^{4}$ Department of Ecology and Evolutionary Biology, University of Michigan, Ann Arbor, MI 48109, USA
}

\begin{abstract}
The 27 extant species of sturgeons and paddlefishes (Order Acipenseriformes) represent a unique and relict lineage of fishes. Producers of coveted black caviar, sturgeons are one of the most valuable wildlife commodities on earth. The group is among the most endangered fishes with all species listed under Convention on International Trade in Endangered Species (CITES) Appendix I (two species) or II (25 species), only two species considered Lower Risk by IUCN, four of the nine US taxa and one Caspian species protected under the Endangered Species Act, and local extinctions recorded for 19 of 27 species. Despite their well-publicized imperilled status, commercial pressure on 15 species persists. Here, after reviewing the biological characteristics of sturgeons and paddlefishes and their commercial use, an overview of global fisheries is presented. The synopsis demonstrates that, with few exceptions, sturgeon and paddlefish are imperilled across the globe and long-term survival in the wild is in jeopardy. All major sturgeon fisheries have surpassed peak productivity levels, with $70 \%$ of major fisheries posting recent harvests $<15 \%$ of historic peak catches and 35\% of the fisheries examined crashing within 7-20 years of inception. Even in Caspian Sea fisheries, the most important globally, present catches are below $10 \%$ of historic peak landings. Improved domestic and international fisheries management and attention to habitat and species restoration is now needed. Although captive rearing offers promise for caviar alternatives and endangered species restoration, it must advance cautiously to avoid environmental harm. To ensure a continued supply of caviar and the survival of these unique fishes we offer recommendations for priority conservation action for the future.
\end{abstract}

Keywords Acipenseriformes, aquaculture, caviar, conservation, Convention on International Trade in Endangered Species

\author{
Correspondence: \\ Phaedra Doukakis, \\ Pew Institute for \\ Ocean Science, 126 \\ East 56th Street, \\ Mezzanine, New York, \\ NY 10022, USA \\ Tel.: 2127560042 \\ Fax: 2127560045 \\ E-mail: pdoukakis@ \\ rsmas.miami.edu \\ *These authors \\ contributed equally to \\ this work. \\ Received 15 July 2004 \\ Accepted 26 July 2005
}

$\begin{array}{ll}\text { Introduction } & \mathbf{2 3 4} \\ \text { Overview of Acipenseriformes } & 234 \\ \text { International harvest and trade } & 240 \\ \text { Major global fisheries } & \mathbf{2 4 1} \\ \text { Caspian Sea } & 241 \\ \text { Black Sea and Sea of Azov } & 245\end{array}$ 
Amur River basin 247

Siberian rivers $\quad 248$

Western North America $\quad 248$

Anadromous species in eastern North America $\quad 249$

Potamodromous species in inland and eastern North America 250

Sturgeon fisheries of the world: observations and recommendations 251

Status of Acipensiformes populations and fisheries $\quad 251$

Recommendations on conservation priorities 253

Acknowledgements $\quad 257$

$\begin{array}{ll}\text { References } & 257\end{array}$

\section{Introduction}

Twenty-seven extant species of sturgeons and paddlefishes (Order Acipenseriformes) inhabit the rivers, estuaries, near-shore oceanic environments and inland seas of the northern hemisphere (Table 1; Fig. 1; Birstein 1993; Grande and Bemis 1996; Bemis et al. 1997; Bemis and Kynard 1997). A unique and relict lineage important in the evolutionary history of fishes, many sturgeons and paddlefishes now face extinction because of overfishing, pollution and habitat degradation (Birstein 1993). Producers of black caviar, the unfertilized eggs of true sturgeon, and commercial roe, the unfertilized eggs of paddlefish, the group has experienced decades of intense exploitation fuelled by a lucrative international caviar market. Their fisheries have undergone boom and bust cycles, with overexploitation resulting in harvest and population declines. Few viable sturgeon fisheries now remain.

Recent published works offer summaries of Acipenseriformes aquaculture, biology, conservation, evolution and genetics (Birstein 1993; Dettlaff et al. 1993; Bemis et al. 1997; Bemis and Kynard 1997; Birstein et al. 1997a,c; Findeis 1997; Choudhury and Dick 1998; Billard and Lecointre 2001; Chebanov and Billard 2001; Fontana et al. 2001; Mims 2001; Van Winkle et al. 2002). After briefly reviewing these topics, we review the status and management of 14 commercially important species, focusing on species for which improvements in fisheries management are most critical to restoration and recovery. Species threatened exclusively by habitat degradation, too endangered to support commercial fishing or fully protected from exploitation are only briefly mentioned.

\section{Overview of Acipenseriformes}

Part of the Gnathostomata or jawed fishes, sturgeons and paddlefishes represent an ancient Actinopterygian lineage. Dating from the Lower Jurassic (200 Myr BP), these 'living fossils' retain primitive characters including a heterocercal caudal fin and ganoid scales (Gardiner 1984). Characters such as a cartilaginous endoskeleton and hyostylic jaw suspension led to early classification as sharks (Bemis et al. 1997). Since their genesis in the Tethys Sea, Acipenseriformes lineages diverged in Europe and Asia and later radiated in North America (Bemis and Kynard 1997; Birstein et al. 1997b). All extant and fossil sturgeons and paddlefishes are from the temperate northern hemisphere with a distribution closely tied to the former Laurasian landmasses (Eurasia, North America) (Grande and Bemis 1996; Bemis et al. 1997). Some of the largest rivers and inland waterbodies are important sturgeon and paddlefish habitats (Table 1; Fig. 1).

The Order Acipenseriformes is divided into two families, Acipenseridae (sturgeon) and Polyodontidae (paddlefish) (Table 1; Berg 1940; Grande and Bemis 1996; Bemis et al. 1997). The 25 extant species of sturgeon have spindle-shaped bodies covered by five rows of bony scutes and snouts with sensory barbells. The two extant species of paddlefish lack scales and scutes and have a large extended rostrum. Some taxonomic designations based upon morphology have been challenged by molecular studies and the true number of species and subspecies remains contentious (Grande and Bemis 1996; Mayden and Kuhajda 1996; Bemis et al. 1997; Birstein and Bemis 1997; Birstein et al. 1997b, 2002; Findeis 1997; Birstein and DeSalle 


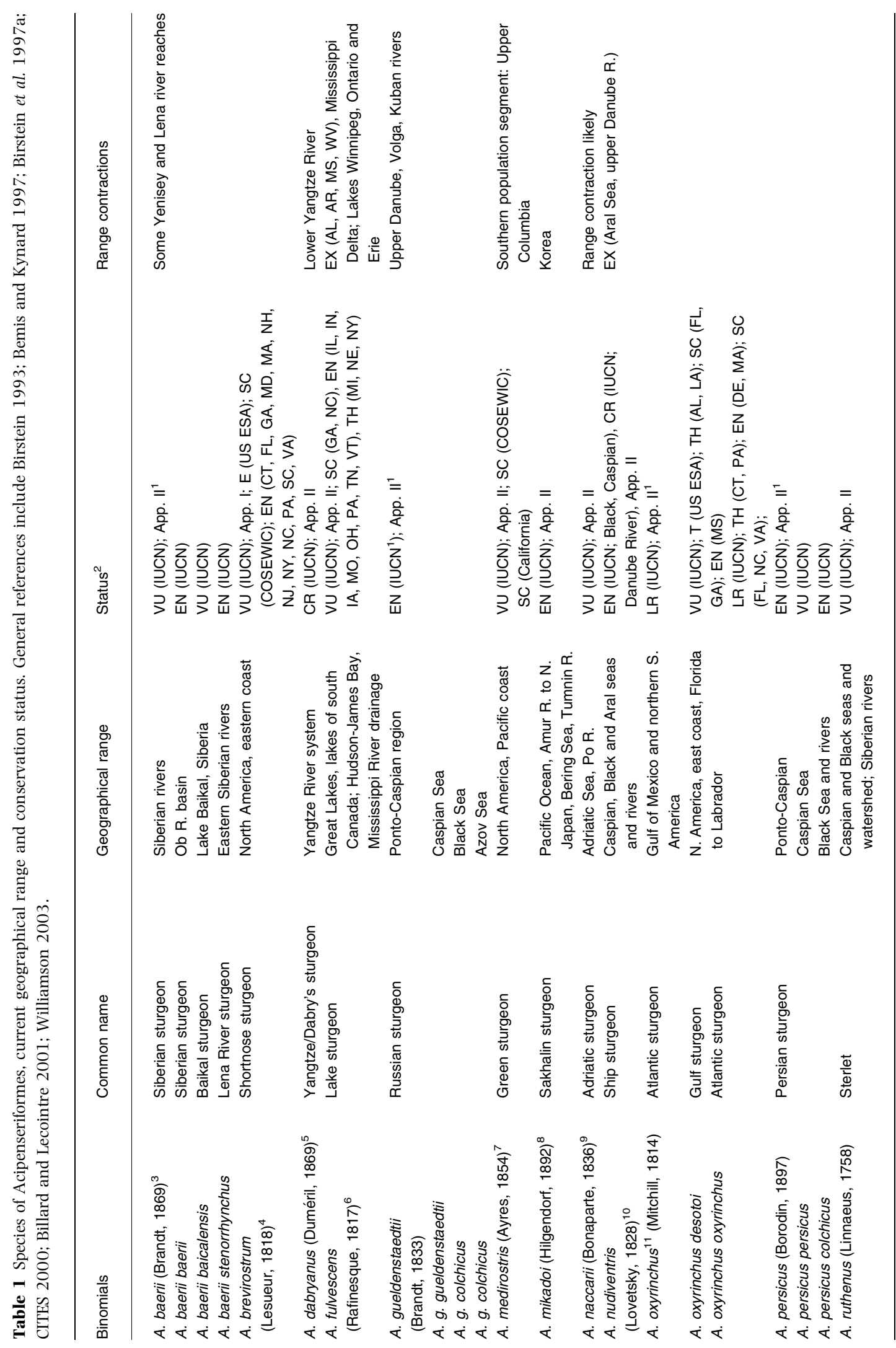

(C) 2005 Blackwell Publishing Ltd, FISH and FISHERIES, 6, 233-265 


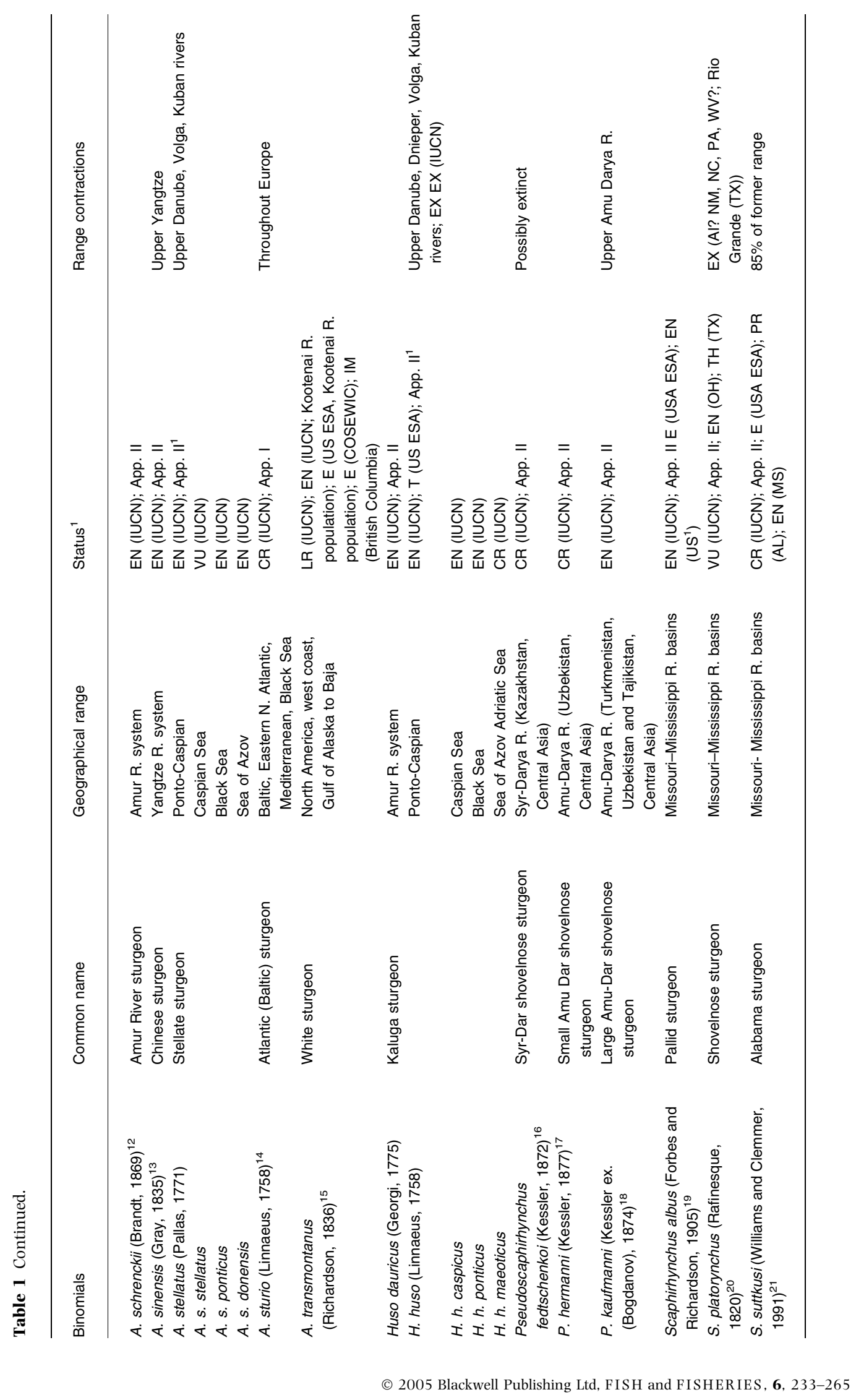




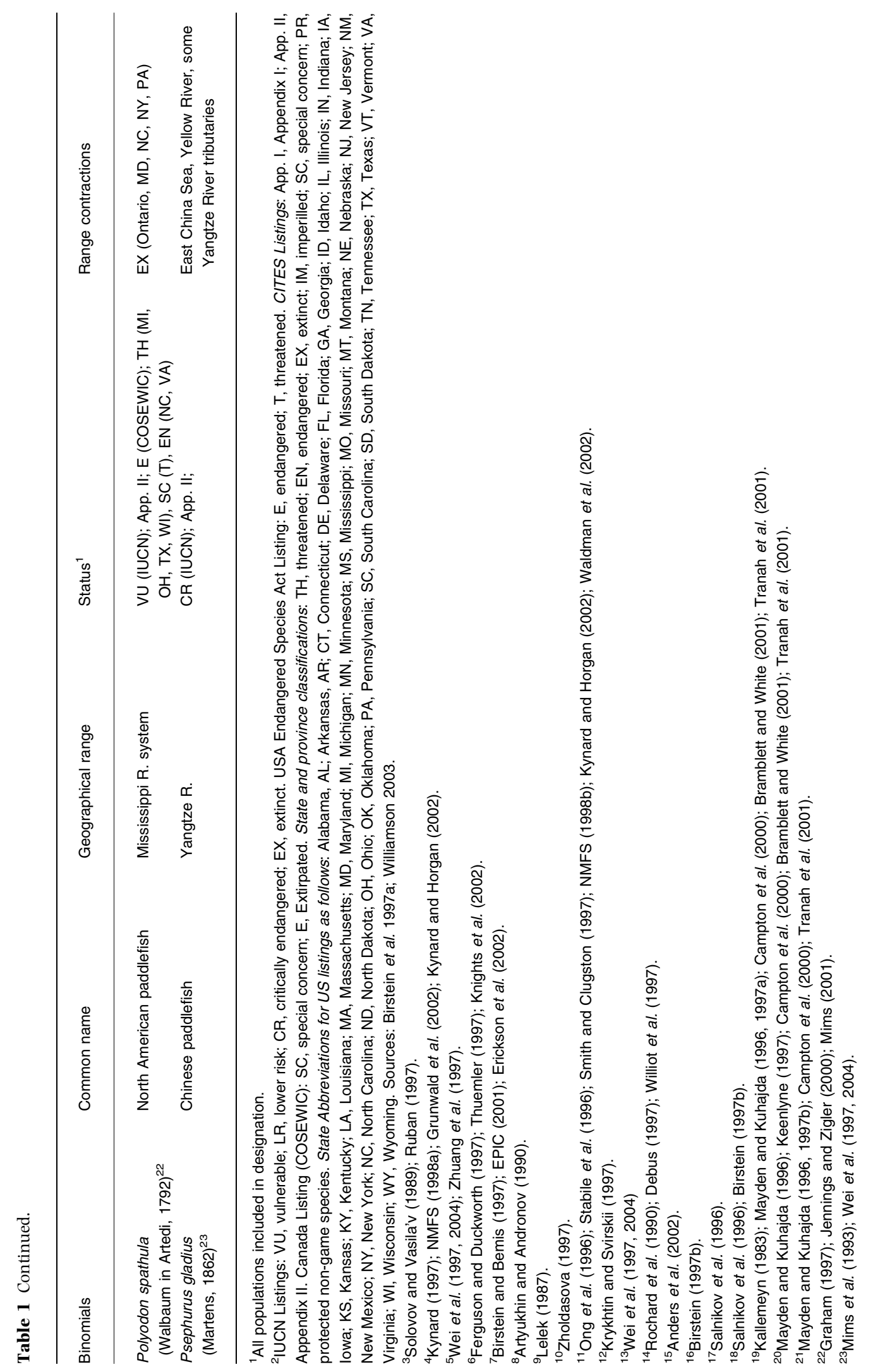




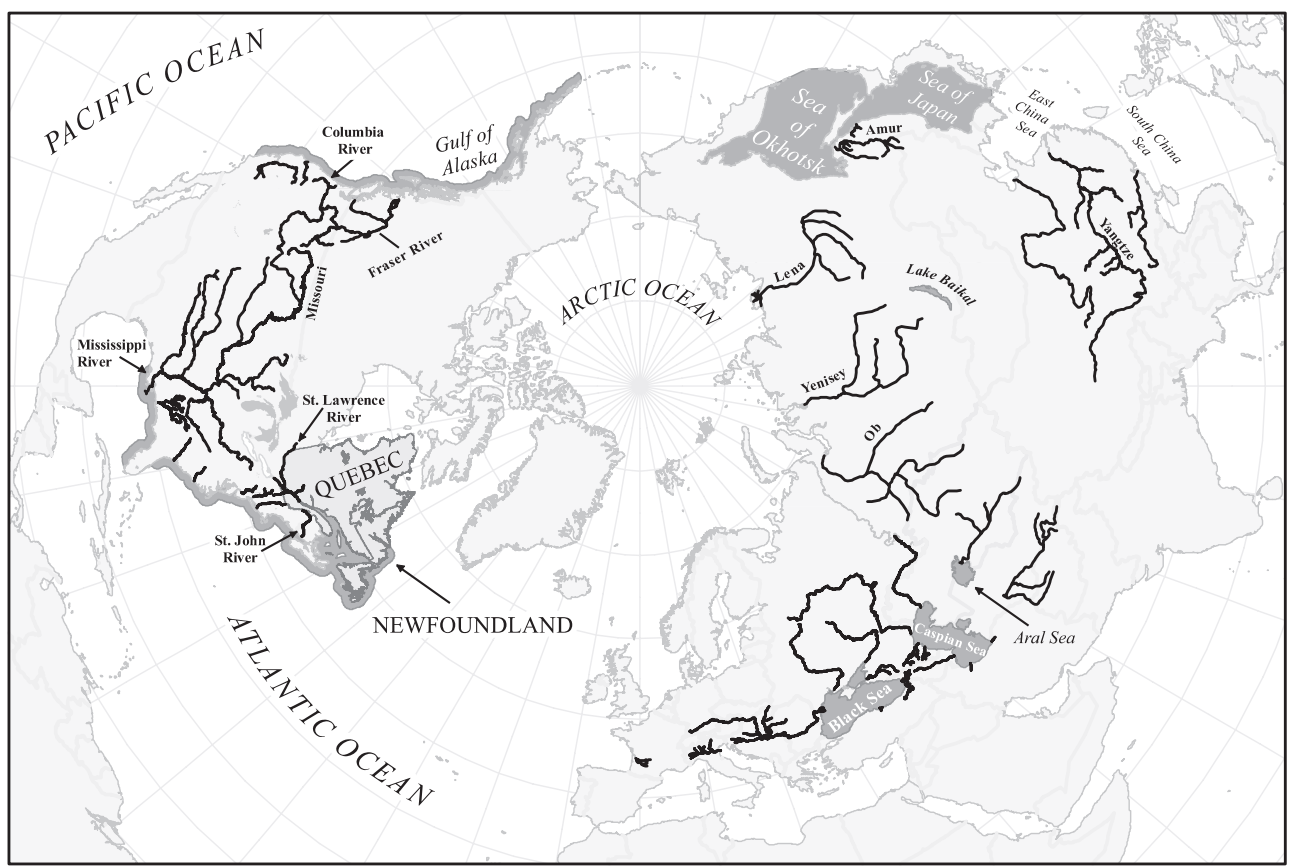

Figure 1 Range and distribution of sturgeon and paddlefish populations.

1998; Doukakis et al. 1999). For example, molecular evidence suggests that the Persian sturgeon ( $A$. persicus) may not be a separate species from the Russian sturgeon (A. gueldenstaedtii), although it is referred to as such herein as it is given distinct fisheries management attention (Berg 1934; Birstein and Bemis 1997; Birstein et al. 2000; Birstein and Doukakis 2002).

Although life-history traits vary among species, Acipenseriformes are generally long-lived fishes that grow and mature slowly (Table 2; Fig. 2; Birstein 1993; Billard and Lecointre 2001). Most species are diadromous (migrating between marine and freshwater systems) and few are potamodromous (migrating within freshwater) with all species reproducing in freshwater, spawning in habitats with hard substrates (e.g. gravel, cobbles, boulders) of varying depths (from a few to over $20 \mathrm{~m}$ ) and current velocities (e.g. from 0.5 to $2.2 \mathrm{~m} \mathrm{~s}^{-1}$ ) (Bemis and Kynard 1997; Billard and Lecointre 2001). The group exhibits one of the highest levels of polyploidy in fishes, ranging from $4 \mathrm{n}$ to $16 \mathrm{n}$ with chromosome numbers from 120 to 500 (Vasil'ev 1999). It also includes the largest freshwater fish, the beluga sturgeon, Huso huso (Table 2).

Nearly all Acipenseriformes are considered threatened or endangered because of the combined effects of overfishing and habitat degradation (Table 1; Rochard et al. 1990; Birstein 1993; De Meulenaer and Raymakers 1996; Billard and Lecointre 2001). Existing since the 5th century $\mathrm{BC}$ and referenced in ancient Greek, Roman and Chinese literature, sturgeon fisheries have intensified as gear and shipping technology has advanced and global demand for caviar increased (Birstein 1993; De Meulenaer and Raymakers 1996; Wei et al. 1997; Luk'yanenko et al. 1999; Secor 2002). Mounting commercial pressure coincided with construction of river dams in Acipenseriformes habitat, blocking spawning ground access and altering spawning habitat, with fish passageways ineffective for mitigation and dam removal a limited option (Scarnecchia et al. 1989; NMFS 1998b; Dubina and Kozlitina 2000; Billard and Lecointre 2001; Friedl and Wüest 2002; Hart et al. 2002; Parsley et al. 2002; Secor et al. 2002). Pollution has also negatively affected reproduction, physiology and food availability as have introduced species, deforestation, water diversion, and gravel and sand extraction Shagaeva et al. 1993; Zaitsev 1993; Altuf'ev 1997; BacalbasaDobrovici 1997; Debus 1997; Ferguson and Duckworth 1997; Gorbunenko et al. 1997; Graham 1997; Krykhtin and Svirskii 1997; Ruban 1997; Bickham et al. 1998; Petr and 
Table 2 Life history and catch statistics for commercial species. General references include Billard and Lecointre (2001) and Williamson (2003). Specific references noted below.

\begin{tabular}{|c|c|c|c|c|c|}
\hline Species & L Max (M) & W Max (kg) & $\begin{array}{l}\text { A Max (years) } \\
\text { Historic/Current }\end{array}$ & Peak catch (tonnes) & Recent catch (tonnes) \\
\hline A. baerii ${ }^{1}$ & 3 & 200 & $? / 60$ & 1769 (1930’s) & $12(2003)$ \\
\hline A. fulvescens & $>2$ & 140 & $150 / 40$ & 2500 (1885; Lake Erie); & 223 (1997 Canada) \\
\hline A. gueldenstaedtii & 2.3 & 100 & $>50 / 38$ & >35 000 (early 1900s; Caspian) & 399 (2003) (335 Caspian) \\
\hline A. medirostris ${ }^{2}$ & 2.9 & 160 & $? / 60$ & $?$ & $?$ \\
\hline A. o. oxyrinchus ${ }^{3}$ & 4.3 & 350 & $60 / ?$ & 3300 (1880; US); >200 (1880; CA) & 73.6 (Canada) \\
\hline A. persicus & 2.4 & 70 & $38 / ?$ & $?$ & 526.2 \\
\hline A. ruthenus & 1.1 & 16 & $26 / 22$ & $?$ & $6(2003)$ \\
\hline A. schrenckil ${ }^{4}$ & 3 & 200 & $? / 45$ & 607 (1891) & $45(2003)$ \\
\hline A. stellatus & 2.2 & 80 & $41 / 30$ & 13700 (1970s; Caspian) & 305 (2003) (284.8 Caspian) \\
\hline A. transmontanus ${ }^{5}$ & 6 & 816 & $>100 / 82$ & $\begin{array}{l}747 \text { (1885; Sacramento-San Joaquin); } \\
2500 \text { (1892; Columbia); } \\
512 \text { (1897; Fraser) }\end{array}$ & 200 (2002) US \\
\hline H. dauricus ${ }^{6}$ & $>5.6$ & 1000 & $? / 55$ & $585(1891)$ & $88(2003)$ \\
\hline H. huso ${ }^{7}$ & $>6$ & 1300 & $100 / 56$ & 14800 (early 1900's; Caspian) & 213.4 (2003) (Caspian 155.4) \\
\hline S. platorynchus ${ }^{8}$ & 1 & $4.5-7$ & $? / 30$ & $?$ & $25(1997)$ \\
\hline P. spathula ${ }^{9}$ & 2.5 & 100 & $? / 30$ & 1105 (1899) & $?$ \\
\hline
\end{tabular}

${ }^{1}$ Ruban (1997,1998); ${ }^{2}$ EPIC (2001); in Erickson et al. (2002); ${ }^{3}$ Smith and Clugston (1997); Gross et al. (2002); ${ }^{4}$ Krykhtin and Svirskii (1997); Wei et al. (1997); Zhuang et al. (2002); ${ }^{5}$ Parsley et al. (1993); Parsley and Beckman (1994); ${ }^{6}$ Krykhtin and Svirskii (1997); ${ }^{7}$ Raspopov (1993a,b); ${ }^{8}$ Keenlyne (1997); Quist et al. (2002); Everett et al. (2003); ${ }^{9}$ Carlson and Bonislawsky (1981); Epifano et al. (1996).

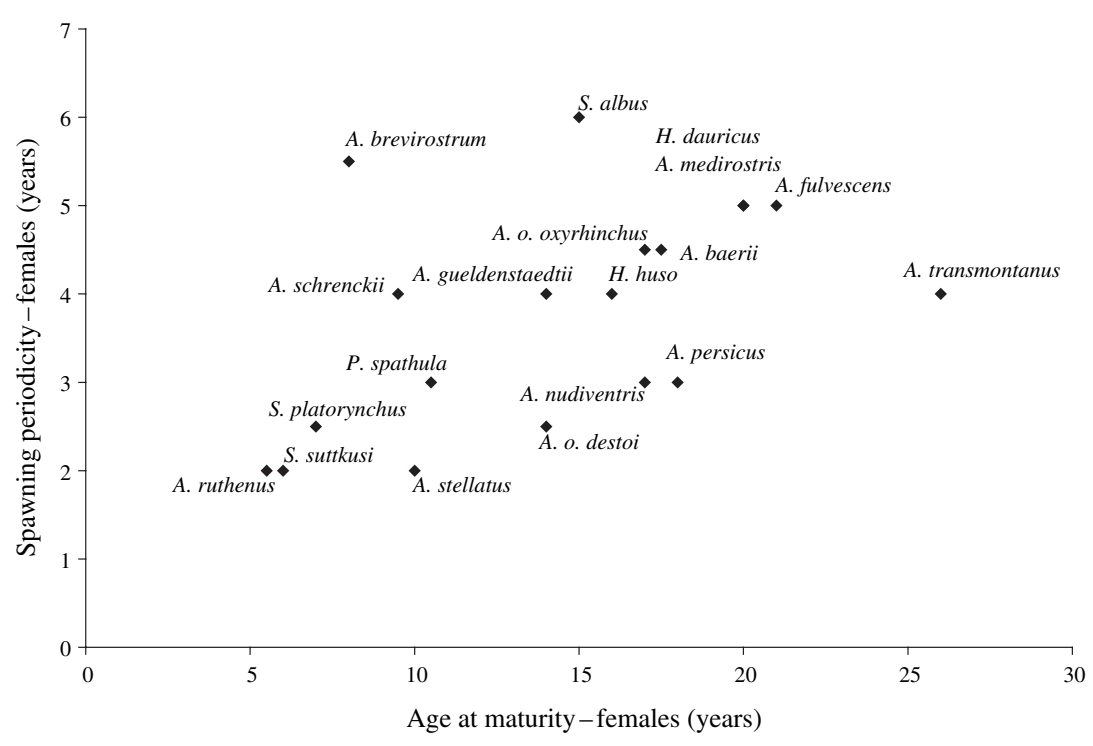

Figure 2 Sturgeon life-history traits; age at maturity and spawning periodicity for females. Values are midrange values of literature survey values. Note same point for H. dauricus and A. medirostris. Epifano et al. 1996; Krykhtin and Svirskii 1997; Ruban 1997, 1998; Mayden and Kuhajda 1997; Smith and Clugston 1997; Wei et al. 1997; Secor et al. 2000; Billard and Lecointre 2001; Erickson et al. 2002; Gross et al. 2002; Quist et al. 2002; Vecsei et al. 2002; Zhuang et al. 2002.

Mitrofanov 1998; Dubina and Kozlitina 2000; Jennings and Zigler 2000; Onders et al. 2001; Daskalov 2002; Friedl and Wüest 2002; Gucu
2002). Combined with late maturity and infrequent reproduction, overfished populations of low abundance have resulted. 


\section{International harvest and trade}

Although commercial caviar trading has flourished globally, the geographical distribution of catch supplying trade has shifted through time. In the 19th century, the United States was the top caviar producer, exporting black caviar from the US waters (primarily from the Atlantic sturgeon A. oxyrinchus oxyrinchus) to Europe (Birstein 1997a; Secor 2002). By the early 1900s, US populations, production and export plummeted (De Meulenaer and Raymakers 1996; Hoover 1998). By the end of the 19th century, Russia was a major caviar trading nation and by the early 20th century Russian sturgeon harvests were seven times greater than historic peak US catches of Atlantic sturgeon (Taylor 1997; Secor et al. 2000). Commercial fisheries in Canada began in the late 19th century, but never commanded a substantial portion of the global market (Williamson 2003). Today, the Caspian Sea nations of Iran, Kazakhstan, Russia and to a lesser extent Azerbaijan and Turkmenistan, dominate the international trade in capture fisheries products while the US, Japan, the European Union and Switzerland are the major importers (De Meulenaer and Raymakers 1996; Hoover 1998; Raymakers 2002).

Sturgeon and paddlefish fisheries catch is currently at its lowest in recent decades (Fig. 3). After peaking in the late 1970s, total global production (capture and aquaculture combined) fell, levelling off in the mid-1990s (Fig. 3). Capture fisheries have accounted for a decreasing percentage of overall production, with aquaculture production recently surpassing wild fisheries production (Fig. 3). In turn, the amount of caviar in international trade has dropped while the amount of meat from aquaculture has increased (Raymakers and Hoover 2002; Raymakers 2002). Aquaculture production of caviar, although increasing, has lagged behind meat production because of the time investment required for maturity and egg production.

Trends in the production and trade in the last two decades have been tied to events in the Caspian Sea region, decreasing fisheries productivity, tightened international trade regulation, and aquaculture. The dissolution of the Soviet Union is considered to be a turning point in sturgeon fisheries management, after which increased illegal harvest and trade ensued, flooding the international market with illegal, low quality, inexpensive caviar (De Meulenaer and Raymakers 1996; Birstein 1997a; Taylor 1997; Vaisman and Raymakers 2001). Global imports of black caviar rose during the early-mid 1990s, with European imports increasing 1.5-2 times and US imports increasing by 100\% (De Meulenaer and Raymakers 1996; Birstein 1997a). Fraudulent mislabelling of caviar became problematic, with low value caviar and caviar from endangered species substituted for highly prized caviar (DeSalle and Birstein 1996; Birstein et al. 1998).

Mounting concern about sturgeons and paddlefishes led to the 1997 listing of all species under the Convention on International Trade in Endangered Species (CITES), a voluntary international

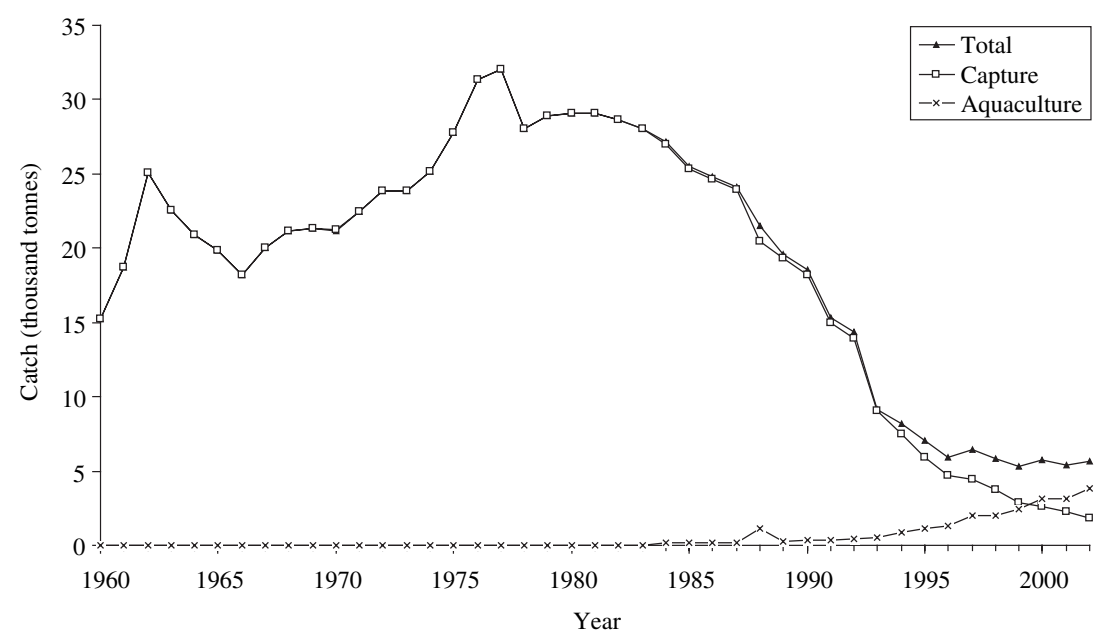

Figure 3 World catch of sturgeon and paddlefish (Source: FISHSTAT Plus, Fisheries Data Analysis Software for Windows, FAO, Rome). 
agreement between governments protecting species threatened by trade and the most significant international act protecting sturgeons and paddlefish. International trade in CITES protected species is accomplished through a trade permit system, for species threatened with extinction (Appendix I) and species of concern (Appendices II and III). Two species of Acipenseriformes are listed under Appendix I, with trade permitted only in special circumstances, and the remaining under Appendix II, with controlled trade permitted (Table 1). Given the challenges of Acipenseriformes conservation, the CITES parties have adopted a series of recommendations outlining conservation measures required for continued trade, including enhanced fishery management and legislation, regional coordination, labelling and control of illegal trade (Conf. 10.12(rev); SC45 Doc.12.1, 12.2). Although implementation of these resolutions has been problematic, greater trade regulation and increased scrutiny of fisheries management have resulted.

Legal and illegal trade in black caviar remains a lucrative business. Legal trade from Russia is estimated at \$40-100 million while the value of illegal Russian caviar exports has been estimated at \$250-400 million (Speer et al. 2000; Stone 2002). Black caviar can command up to US\$5000.00/kg for high quality beluga, with other wild and aquaculture caviar and roe commanding less (Table 3). Prices for both wild origin and aquaculture caviar have risen as wild origin caviar has

Table 3 Caviar prices (\$US, 2004) in internet survey.

\begin{tabular}{llcl}
\hline $\begin{array}{l}\text { Product } \\
\text { name }\end{array}$ & Species & $\begin{array}{l}\text { Price } \\
(\$ / \mathrm{oz})\end{array}$ & $\begin{array}{l}\text { Price } \\
(\$ / \mathrm{kg})\end{array}$ \\
\hline Beluga & Huso huso & $50-150$ & $1764-5291$ \\
Osetra & Acipenser gueldenstaedtii & $37-90$ & $1323-3174$ \\
Sevruga & A. stellatus & $25-80$ & $882-2822$ \\
White & A. transmontanus & $28-32$ & $970-1111$ \\
Paddlefish & Polyodon spathula & $11-38$ & $381-1340$ \\
Hackleback & S. platorynchus & $11-38$ & $381-1340$ \\
Baerii & A. baerii & $30-40$ & $1058-1411$ \\
Persian & A. persicus & 75 & 2645 \\
Salmon & & $2-14$ & $79-494$ \\
Whitefish & & $2-10$ & $71-353$ \\
Trout & & $4-16$ & $141-564$ \\
Bowfin & & 17 & 600 \\
\end{tabular}

Companies surveyed included Caviar direct, Caviar express, Caviar Russe, Marky's caviar, Mackenzie limited, Petrossian, Plaza de Caviar, The Golden Egg, and Tsar Nicoulai. become scarcer and the taste and quality of aquaculture caviar has been improved, prompting greater acceptance in the marketplace (De Meulenaer and Raymakers 1996; Raymakers and Hoover 2002; Raymakers 2002).

The international caviar trade remains dominated by product from the Caspian and Black Sea regions. Four Caspian/Black Sea species, beluga, stellate (A. stellatus), Russian and Persian, have supplied over $95 \%$ of the internationally traded caviar in recent years (2003: 94.8\%; 2004: 99.6\%). Other commercially important species include the Caspian Sea sterlet (A. ruthenus), Amur River sturgeon [kaluga sturgeon (H. dauricus), Amur sturgeon (A. schrenckii)], Siberian sturgeon (A. baerii), and North American species [white sturgeon (A. transmontanus), Atlantic sturgeon (A. oxyrinchus), lake sturgeon (A. fulvescens), American paddlefish (Polyodon spathula), shovelnose sturgeon (Scaphirhynchus platorynchus), and green sturgeon (A. medirostris)]. Species not commercially important and not discussed herein include A. mikadoi, A. naccarii, A. sturio, Yangtze River species (A. dabryanus, A. sinensis, P. gladius), Siberian populations of the sterlet, Aral Sea watershed species (A. nudiventris, P. kaufmanni, P. hermanni, $P$. fedtschenkoi), and US taxa listed under the US Endangered Species Act (ESA) (A. brevirostrum, $S$. albus, S. suttkusi, white sturgeon, Kootenai river, A. o. desotoi) (Table 1). Ship sturgeon (A. nudiventris) in the Caspian and Black Sea, although commercially exploited to a small extent and highly endangered, is not considered here because of the lack of data about the fishery (Table 1).

\section{Major global fisheries}

\section{Caspian Sea}

Fed by over 100 river systems, the Caspian Sea, at $384000 \mathrm{~km}^{2}$, is the largest inland water body in the world and harbours the greatest abundance of sturgeon on the planet and largest and most important sturgeon fisheries (Figs 4 and 5; Dumont 1995; De Meulenaer and Raymakers 1996; Levin 1997; Secor et al. 2000). Six species of sturgeon occur in the basin [beluga, Russian, Persian, sterlet, stellate, ship (A. nudiventris)], with Russian and stellate sturgeons the most abundant and ship sturgeon the rarest (Levin 1997; CITES 2000). All species except sterlet (a potamodromous species) are anadromous, although landlocked freshwater 


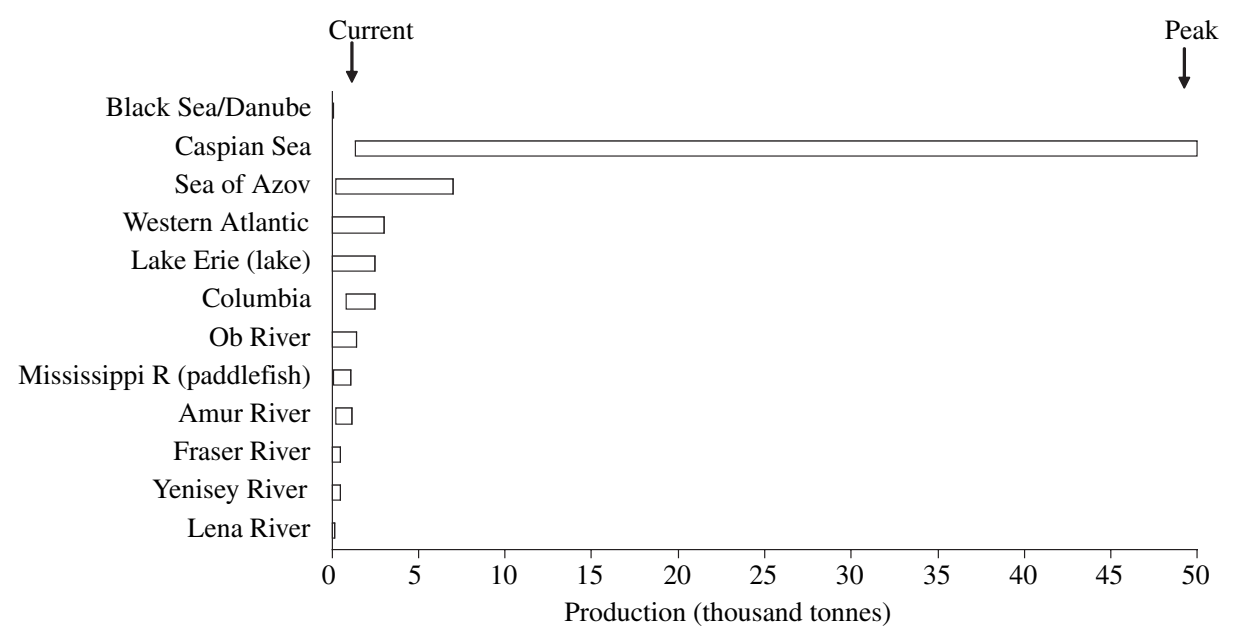

Figure 4 Peak (right/higher value) and current (left/lower value) sturgeon fishery production by region.

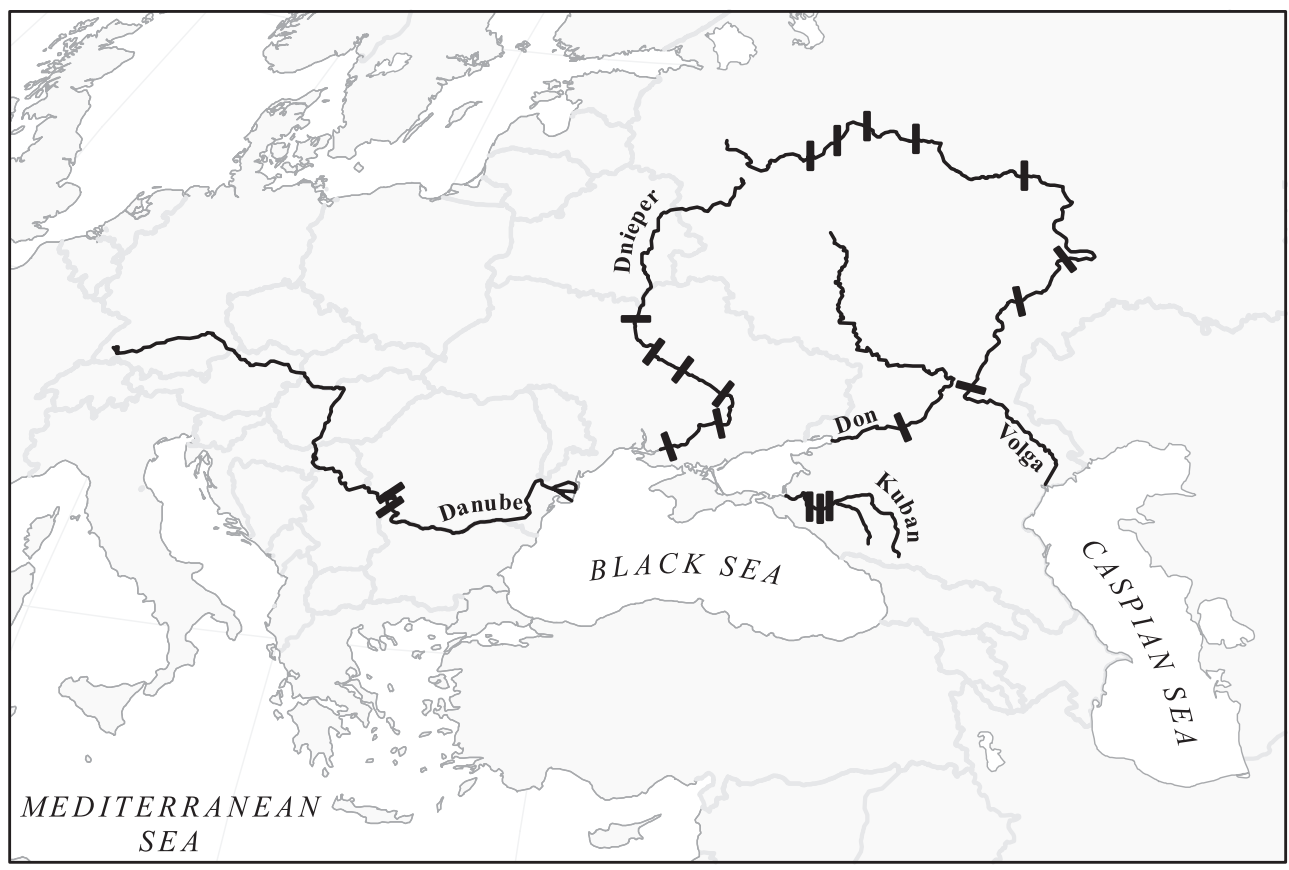

Figure 5 Caspian, Black and Sea of Azov regional map showing principal spawning rivers. Hatch marks indicate river dams.

populations occur (Sokolov and Tsepkin 1996; Hensel and Holcik 1997; CITES 2000; Arai and Miyazaki 2001; Chebanov and Billard 2001). Anadromous species typically consist of autumnal and vernal (sometimes divided into early and late races), which migrate upriver in two separate seasonal runs, coincident with fishing seasons (Hensel and Holcik 1997; Levin 1997). All anadromous species but the Persian sturgeon, which occurs mainly in the southern Caspian region, are distributed throughout the Caspian Sea, while the freshwater sterlet primarily inhabits the Volga River (Berg 1948; Artyukhin and Zarkua 1986; Vlasenko et al. 1989; Artyukhin 1997). These species vary in life history, with all species but the sterlet requiring at least 10 years to mature (Table 2; Fig. 2).

Historically the Volga River has been the most important river for the fishery and for spawning but dam construction on the Volga River has deprived sturgeons of between $30 \%$ and $90 \%$ of their former 
spawning grounds (Fig. 5; De Meulenaer and Raymakers 1996; Khodorevskaya et al. 1997; Secor et al. 2000). Currently the Ural River is the only free-flowing river feeding the Caspian Sea where sturgeons reproduce unhindered by dams, although sedimentation and pollution have caused a $50 \%$ loss in spawning area (De Meulenaer and Raymakers 1996; Khodorevskaya et al. 1997; in Secor et al. 2000). The Gorganrug, Kura, Sefidrud, Sulak, Tajen and Terek rivers may also provide sturgeon habitat (Khodorevskaya et al. 1997; CITES 2000). After hatching in river systems, anadromous sturgeons migrate into the sea to mature, returning to river systems for spawning, with homing fidelity to natal rivers uncertain (Khodorevskaya and Krasikov 1999; Khodorevskaya et al. 2000; Billard and Lecointre 2001; Kynard et al. 2002).

The northern Caspian Sea (specifically the Volga River) historically supported the bulk of the sturgeon catch with southern Caspian Sea catch increasing in recent years (De Meulenaer and Raymakers 1996; Artyukhin 1997; Khodorevskaya et al. 1997). Catch in the Caspian Sea peaked in the 17th century (50 000 tonnes) followed by declines and rebounds due to reduced effort coincident with wars (e.g. 1912-1924) and fisheries regulation. In the 20th century, catch peaked in the 1970s (27 300 tonnes), but declined steadily thereafter to 1388 tonnes in 2002 (Fig. 4; FISHSTAT; De Meulenaer and Raymakers 1996; Artyukhin 1997; Birstein 1997a; Levin 1997; Khodorevskaya et al. 2000; Secor et al. 2000; Vaisman and Raymakers 2001).

Caspian Sea catch is comprised of Russian, stellate, and Persian sturgeon and to a lesser extent, beluga and sterlet (Artyukhin 1997; Khodorevskaya and Krasikov 1999; Moghim and Neilson 1999). Beluga catch has steadily declined from a peak in the early 1900s (14 800 tonnes) while catch of Russian sturgeon has been more variable, also exhibiting an overall decline (Table 2; Fig. 6a,b). Fewer data on the stellate sturgeon fishery are available with catch declines evident from 1970 to 2002 (Table 2; Fig. 6c). Although historic data on Persian and sterlet sturgeon are scarce, Persian sturgeon catch has risen in recent years while sterlet catch has never been significant (Table 2).

Published studies illustrate that population sizes of all species but Persian sturgeon have declined, with some estimates suggesting 80-90\% decreases in the last 30-40 years (Khodorevskaya and Krasikov 1999; Khodorevskaya et al. 2002). The number of beluga sturgeon annually entering the
Volga to spawn dropped from 26000 during 196165 to 2800 during 1998-2002, while only 2500 individuals migrated up the Ural River in 2002 (Khodorevskaya et al. 1997, 2000; J. A. Armstrong, unpublished data). For beluga, Russian, stellate and sterlet sturgeon, size at maturity, growth rate and average age of the population and of spawning individuals have decreased (Raspopov 1993a,b; Khodorevskaya et al. 1995, 1997, 2000, 2002; Khodorevskaya and Krasikov 1999; Khodorevskaya 1999; Moghim and Neilson 1999; Kuznetsov 2000). Sex ratios have shifted, with some populations consisting of fewer than 20\% females (Khodorevskaya 1999; in De Meulenaer and Raymakers 1996; Vaisman and Raymakers 2001).

In contrast, abundance estimates generated through sea trawl studies conducted by range states in compliance with CITES resolutions suggest large population sizes and increasing abundance. Independent review of the studies could not replicate the findings, suggesting erroneous calculations overestimating abundance (Pikitch and Lauck, unpublished data in Pearce 2003). Alternative calculations indicate dangerously small populations of beluga and harvest quotas equivalent to removal of nearly all mature individuals (Pikitch and Lauck unpublished data; Ginsberg 2002). Current, accepted population assessments are still unavailable.

The Caspian Sea fishery was reportedly tightly regulated in Soviet times, with fishing banned in the open sea, catch quotas, seasonal closures and gear restrictions (De Meulenaer and Raymakers 1996; Birstein 1997a; Levin 1997; Taylor 1997; Khodorevskaya et al. 2000; Secor et al. 2000). The dissolution of the Soviet Union in 1991 led to the division of fishing rights among the new independent states, sea fishing, and increased illegal harvest and trade (De Meulenaer and Raymakers 1996; Levin 1997; Taylor 1997). In 1997, the Caspian nations re-instituted the sea fishing ban, allowing harvest only in rivers, but the ban is not adequately enforced (Bauer 1997).

Fisheries are now managed and regulated by individual countries through gear, catch and seasonal restrictions, with exports managed under CITES (De Meulenaer and Raymakers 1996; CITES 2000; Khodorevskaya et al. 2000; Vaisman and Raymakers 2001). Recommendations set forth after a CITES Review of Significant Trade (A CITES action when Appendix II species are thought to be traded without adequate implementation of CITES provisions. Beluga, Persian, Russian, ship, sterlet, and 
(a)

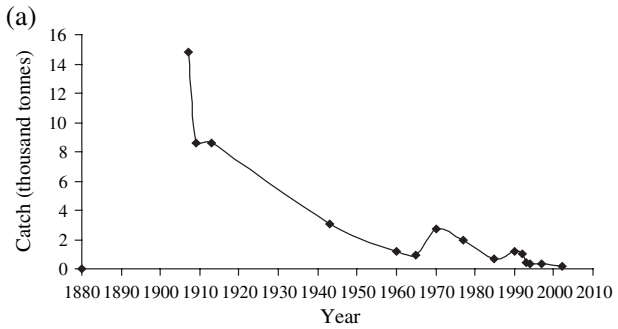

(c)

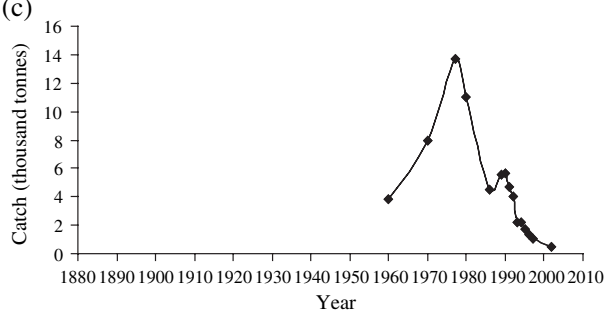

(e)
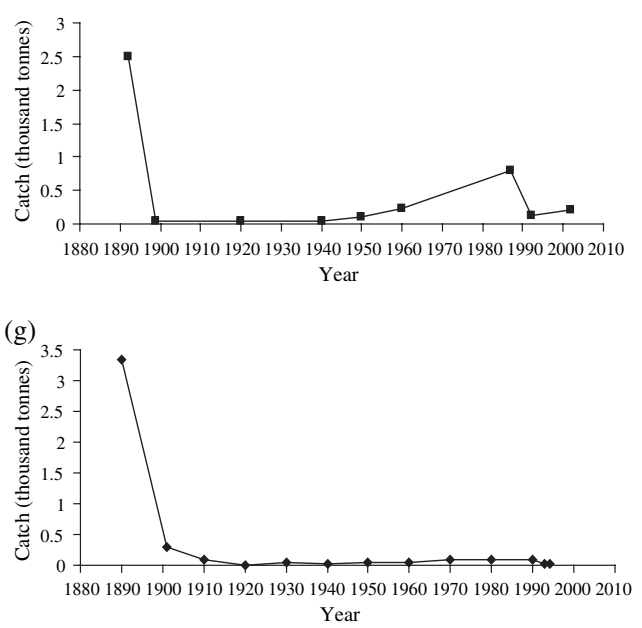

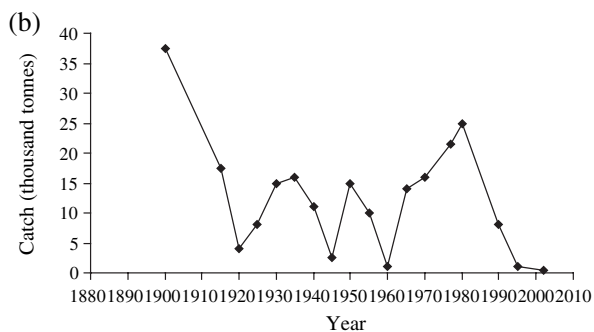

(d)
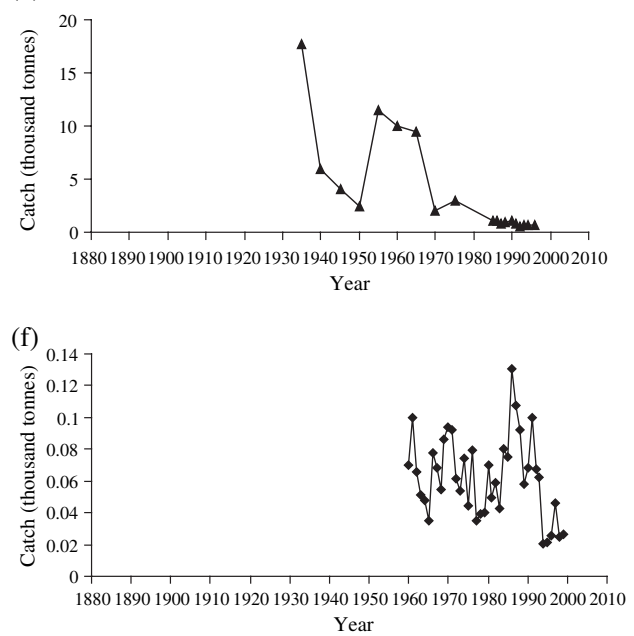

(h)

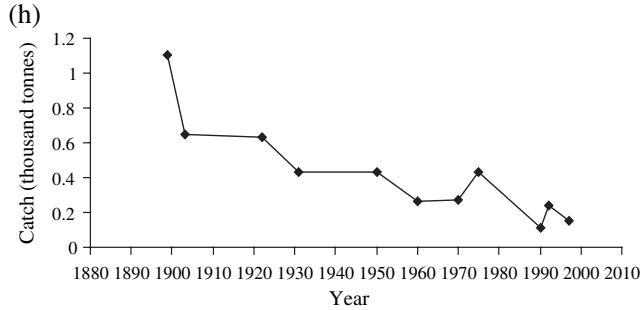

Figure 6 Catch data over time for select species. (a) Beluga (Caspian Sea) (Raspopov 1993a; in Khodorevskaya et al. 1997, 2000; CITES 2000; Altukhov and Evsyukov 2001; http://www.cites.org); (b) Russian sturgeon (Caspian Sea) (De Meulenaer and Raymakers 1996; Khodorevskaya et al. 1997; CITES 2000; Altukhov and Evsyukov 2001; http:// www.cites.org); (c) Stellate sturgeon (Caspian Sea) (Khodorevskaya et al. 1997; CITES 2000; Altukhov and Evsyukov 2001; http://www.cites.org); (d) Siberian sturgeon (Ob, Yenisey, Lena Rivers) (Ruban 1997; CITES 2000); (e) white sturgeon (Columbia River) (Rieman and Beamesderfer 1990; Parsley and Beckman 1994; Williamson 2003); (f) green sturgeon (EPIC 2001). (g) Atlantic sturgeon (US landings only until fishery closure) (Smith and Clugston 1997; Atlantic Sturgeon Status Review Team 1998; Waldman and Wirgin 1998; Secor 2002); (h) Paddlefish (Commercial harvest only) (Carlson and Bonislawsky 1981; CITES 2000). Note different scales for each graph.

stellate, sturgeon were reviewed) called on Caspian nations to establish coordinated basin-wide management, long-term, comprehensive stock surveys, measures to combat illegal harvest and improve fishery management (SC45 Doc.12.2; Conf. 12.7). Export quotas were to be based on a cooperative management strategy, agreed upon by all Caspian nations, and submitted to the CITES Secretariat for review by December 31 of the year preceding export. Since 2001, approved quotas have been reduced for all species but Persian sturgeon (Table 4, Fig. 7). Problems with CITES compliance has resulted in temporary fishery closures, trade bans and zero quotas, but long-term bans have never been instituted despite the fact that many recommendations remain outstanding (Raymakers 2002; Raymakers 


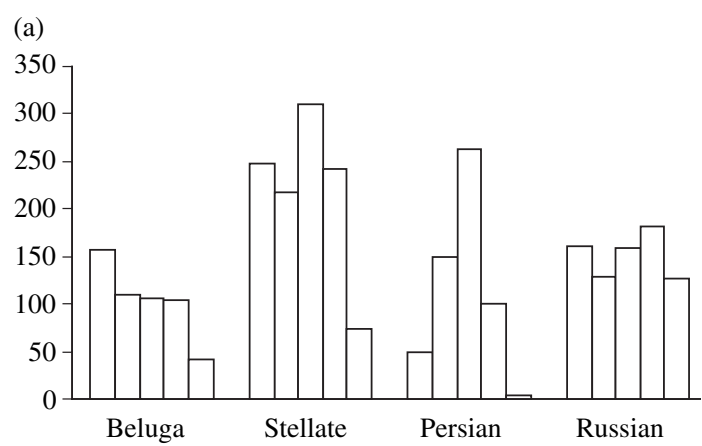

(b)

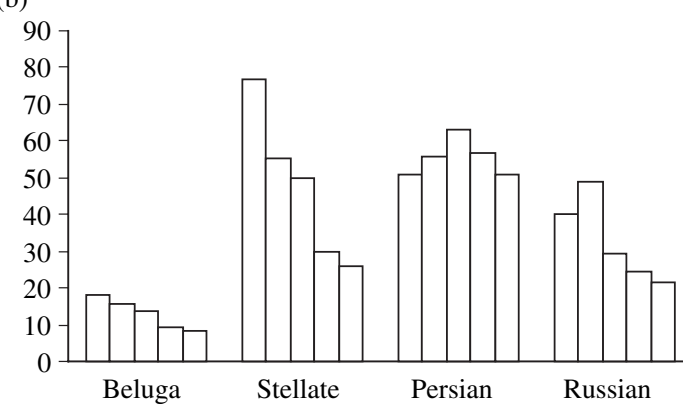

Figure 7 Evolution of CITES export quotas for four main commercial species 2001-2005. (a) Meat; (b) caviar.

and Hoover 2002; Stone 2002; Ginsberg 2002). Critics believe enforcement of resolutions has been weak and fishery collapse and/or extinction may be imminent. Illegal harvest still exceeds legal catch by several orders of magnitude and recent news suggests most black caviar in trade is illegal (Vaisman and Raymakers 2001; Agence France Presse 2004; ITAR-TASS News Agency 2004). Domestic caviar sale and consumption in Caspian range countries has reportedly increased since CITES listing, making it questionable as to whether export restrictions have resulted in decreased harvest (Vaisman and Raymakers 2001; Raymakers and Hoover 2002). Export quotas are still being approved in the absence of accepted population abundance estimates.

In the 1950s, captive propagation programmes (whereby sturgeons are bred in captivity for restocking wild populations) were created to ameliorate population declines and the loss of natural recruitment (Levin 1997; CITES 2000; Secor et al. 2000). In the early 1990s, 60-70 million individuals were released from hatcheries annually, including beluga, Persian, Russian, ship, stellate and sterlet (Levin 1997; CITES AC 18 Doc 17.12002 ).
It is speculated that $30 \%$ (Volga River stellate and Russian sturgeon) to $90 \%$ (Volga River beluga) of wild individuals are of hatchery origin (De Meulenaer and Raymakers 1996; Khodorevskaya 1999; Khodorevskaya et al. 2000; Secor et al. 2000). As released fish have not been tagged or marked, estimating their contribution to the current population is impossible, although some programmes are beginning to address this issue (Doukakis et al. 2004). Hatchery programmes have been faltering in recent years because of inadequate financing and a scarcity of breeding females (Khodorevskaya 1999; Khodorevskaya et al. 2000; Secor et al. 2000; Doukakis et al. 2004).

\section{Black Sea and Sea of Azov}

The Black Sea, Sea of Azov, and their watersheds once harboured some of the most productive sturgeon fisheries (Figs 4 and 5; Birstein 1996; Vaisman and Raymakers 2001). The six species found in the Caspian Sea inhabit these basins and the Baltic sturgeon, A. sturio, formerly occurred in the Black Sea, but has been extirpated (Hensel and Holcik 1997). The region now contributes little to international trade, with 6.5 tonnes of caviar and 50 tonnes of meat $(5 \%$ and $13 \%$ of total export, respectively) exported in 2004 from the Black Sea (Table 4). Beluga and ship sturgeons are scarce or extinct in the Sea of Azov, with the last records of beluga from the mid 1980s (in Khodorevskaya 1999; CITES 2000; Billard and Lecointre 2001). Sterlet is plentiful in the Danube and Dneister rivers, but its status in the Sea of Azov is uncertain (Bacalbasa-Dobrovici 1997; Hensel and Holcik 1997; CITES 2000). Persian sturgeon, with populations in Georgia (Rioni River), Russia (Don River), and Turkey, have experienced a 50\% decline in the last three generations (AC 18 Doc 17.1 2002). As in the Caspian, dams have practically eliminated natural reproduction of populations in the upper and middle Danube River, and in the Dneister River and the Don and Kuban rivers of the Sea of Azov (Fig. 5; Bacalbasa-Dobrovici 1997; Gorbunenko et al. 1997; Hensel and Holcik 1997; CITES 2000; Billard and Lecointre 2001; Dubina and Kozlitina 2000; Friedl and Wüest 2002).

Although sturgeons historically reproduced in many Black Sea river systems, only the Danube River currently supports significant spawning populations (Fig. 5; Bacalbasa-Dobrovici 1997; Hensel and Holcik 1997; CITES 2000). Stellate, beluga and 
Table 4 CITES export quotas 2001-2005 for meat (M) and caviar (C).

\begin{tabular}{|c|c|c|c|c|c|c|c|c|c|c|c|c|c|}
\hline Species & $\begin{array}{l}\text { Country/ } \\
\text { Region }\end{array}$ & $\begin{array}{l}2001 \\
(M)\end{array}$ & $\begin{array}{l}2002 \\
(M)\end{array}$ & $\begin{array}{l}2003 \\
(\mathrm{M} / \mathrm{FC})\end{array}$ & $\begin{array}{l}2004 \\
(\mathrm{M} / \mathrm{FC})\end{array}$ & $\begin{array}{l}2005 \\
(\mathrm{M} / \mathrm{FC})\end{array}$ & $\begin{array}{l}\text { Trend } \\
\text { (M) }\end{array}$ & $\begin{array}{l}2001 \\
\text { (C) }\end{array}$ & $\begin{array}{l}2002 \\
\text { (C) }\end{array}$ & $\begin{array}{l}2003 \\
\text { (C) }\end{array}$ & $\begin{array}{l}2004 \\
\text { (C) }\end{array}$ & $\begin{array}{l}2005 \\
\text { (C) }\end{array}$ & $\begin{array}{l}\text { Trend } \\
\text { (C) }\end{array}$ \\
\hline \multirow[t]{4}{*}{ A. gueldenstaedtii } & Azov & 17.0 & 0 & 5.0 & 0 & 0 & $\downarrow$ & 2.0 & 10.0 & 0.3 & 0 & 0 & $\downarrow$ \\
\hline & Black & 19.1 & 6.0 & 8.5 & 25.0 & 0.8 & $\mathrm{~F}$ & 1.8 & 1.22 & 1.12 & 1.1 & 0.16 & $\downarrow$ \\
\hline & Caspian & 124.9 & 122.4 & 146.3 & 156.7 & 126.1 & $\mathrm{~F}$ & 36.4 & 37.8 & 27.8 & 23.3 & 21.1 & $\downarrow$ \\
\hline & Total & 161.0 & 128.4 & 159.8 & 181.7 & 126.9 & $\mathrm{~F}$ & 40.2 & 49.0 & 29.2 & 24.4 & 21.3 & $\downarrow$ \\
\hline A. persicus & Caspian & 50.0 & 150.0 & 263.1 & 100 & 4.0 & $\mathrm{~F}$ & 51.0 & 56.0 & 63.0 & 57.6 & 51.0 & $\mathrm{~F}$ \\
\hline \multirow[t]{3}{*}{ A. ruthenus } & Black & 0 & 0 & 0 & 1 & 1 & $\uparrow$ & 0 & 0 & 0 & 0.1 & 0.1 & $\uparrow$ \\
\hline & Caspian & 0 & 0 & 0 & 0 & 0 & $\leftrightarrow$ & 0.1 & 0.1 & 0.1 & 0.1 & 0.1 & $\leftrightarrow$ \\
\hline & Total & 0 & 0 & 0 & 1 & 1 & $\uparrow$ & 0.1 & 0.1 & 0.1 & 0.2 & 0.2 & $\uparrow$ \\
\hline \multirow[t]{4}{*}{ A. stellatus } & Azov & 17.0 & 8.0 & 1.5 & 0 & 0 & $\downarrow$ & 2.5 & 0 & 0.1 & 0 & 0 & $\downarrow$ \\
\hline & Black & 21.0 & 3.0 & 3.5 & 2.2 & 2.2 & $\downarrow$ & 2.05 & 1.47 & 1.2 & 0.9 & 0.9 & $\downarrow$ \\
\hline & Caspian & 209.2 & 206.3 & 305.9 & 239.3 & 71.8 & $\mathrm{~F}$ & 72.1 & 53.9 & 48.4 & 29.0 & 25.2 & $\downarrow$ \\
\hline & Total & 247.2 & 217.3 & 310.9 & 241.5 & 74.0 & $\mathrm{~F}$ & 76.7 & 55.4 & 49.7 & 29.9 & 26.1 & $\downarrow$ \\
\hline \multirow[t]{3}{*}{ H. huso } & Black & 40.0 & 19 & 19 & 21 & 19.5 & $\mathrm{~F}$ & 5.55 & 4.6 & 4.67 & 4.67 & 4.055 & $\downarrow$ \\
\hline & Caspian & 116.9 & 90.7 & 86.5 & 83.2 & 22.9 & $\downarrow$ & 12.5 & 11.24 & 12.66 & 4.48 & 4.47 & $\downarrow$ \\
\hline & Total & 156.9 & 109.7 & 105.5 & 104.3 & 42.4 & $\downarrow$ & 18.02 & 15.84 & 17.33 & 9.15 & 8.53 & $\downarrow$ \\
\hline \multirow[t]{3}{*}{ A. schrenckii } & China & 0 & 0 & 0 & 0 & Ip & $\leftrightarrow$ & 2.15 & 2.51 & 2.51 & 0 & Ip & $\leftrightarrow$ \\
\hline & Russia & 4 & 1.5 & 1.5 & 0 & Ip & $\downarrow$ & 2.14 & 0.35 & 0.35 & 0 & Ip & $\downarrow$ \\
\hline & Total & 4 & 1.5 & 1.5 & 0 & Ip & $\downarrow$ & 5.29 & 2.86 & 2.86 & 0 & Ip & $\downarrow$ \\
\hline \multirow[t]{3}{*}{ H. dauricus } & China & 0 & 0 & 0 & 0 & Ip & $\leftrightarrow$ & 3.43 & 3.43 & 3.43 & 0 & Ip & $\leftrightarrow$ \\
\hline & Russia & 20 & 5 & 5 & 0 & Ip & $\downarrow$ & 7 & 2.3 & 1 & 0 & Ip & $\downarrow$ \\
\hline & Total & 20 & 5 & 5 & 0 & Ip & $\downarrow$ & 10.43 & 5.73 & 4.43 & 0 & Ip & $\downarrow$ \\
\hline A. fulvescens & Canada & 170 & 170 & 101.5 & 0 & - & $\downarrow$ & 0.5 & 0.5 & 0 & 0 & - & $\downarrow$ \\
\hline A. o. oxyrinchus & Canada & 58 & 58 & 73.6 & 0 & - & $\downarrow$ & 0.5 & 0.05 & 0 & 0 & - & $\downarrow$ \\
\hline A. transmontanus & US & 3 & 3 & 3 & 0 & - & $\downarrow$ & 0 & 0 & 0 & 0 & - & $\downarrow$ \\
\hline
\end{tabular}

Export quotas were not issued for wild products from A. baerii, A. medirostris, S. platorynchus or $P$. spathula during this period. Trend arrows display increasing $(\uparrow)$, decreasing $(\downarrow)$, steady $(\leftrightarrow)$ or fluctuating trends $(F)$ in export quotas. FC, Food and Canned Products; Ip, discussions in progress for issuing quota.

Russian sturgeon have been extirpated from the upper Danube (source-Vienna), are critically endangered or rare in the middle portion of the river (Vienna-Iron Gates Dam I), and are vulnerable in the lower river (Iron Gates Dam I-mouth) (Fig. 5; Bacalbasa-Dobrovici 1997; Hensel and Holcik 1997). Sterlet occurs in the middle and lower reaches and rarely in the upper Danube (BacalbasaDobrovici 1997; Hensel and Holcik 1997). Ship sturgeon is critically endangered throughout the Danube basin, existing only as a freshwater form (Hensel and Holcik 1997). Other important rivers include the Bug, Coruh, Dnieper, Dniester, Inguri, Kizilirmak, Lenkoranka, Rioni, Supsa, Tisza and Yesilirmak in the Black Sea, and the Don and Kuban rivers in the Sea of Azov although it is unlikely that natural reproduction continues in the Sea of Azov.

Catch in the Black Sea watershed is conducted by Romania, Ukraine, Bulgaria and Serbia. Historic catch records, available mostly for the Danube River, indicate declines in the Danube River fishery as early as the 19th century, continuing through the 1960s (300 tonnes; 1960) the middle 1990s (9.4 tonnes; 1995) (Bacalbasa-Dobrovici 1997). Catch of Russian sturgeon has fluctuated, from 25 tonnes annually in the Danube from 1958 to 1981 to 11 tonnes in 1999 to 19 tonnes in 2003 (Table 2; CITES 2000). Beluga sturgeon declines in the Danube River were reported beginning in the 16 th century, with recent catches below 60 tonnes (Hensel and Holcik 1997). Stellate catch has always been small while sterlet catch has been higher, dominated by Bulgaria and export accomplished by Romania (Table 4; CITES 2000). Published abundance estimates are not available for Black Sea populations but an increasing proportion of immature animals was observed in stellate populations in the Danube River (Ceapa et al. 2002).

In the Sea of Azov legal fishing by Russia and Ukraine has practically ceased and no export quotas have been issued for the last 2 years (Table 4). Peak catch from the 1930s to 1962 was 7000 tonnes, declining to 1103 tonnes in the early $1960 \mathrm{~s}$ to 200 tonnes by 1998 to 70 tonnes in 2003 , 
dropping up to $90 \%$ in some regions between 1993 and 1998 (Vaisman and Raymakers 2001). In the mid-1980s, the biomass of stellate and beluga sturgeon in the Sea of Azov was 12390 tonnes and 1170 tonnes, respectively, before pollution related die-offs that began in 1990 (Volovik et al. 1993 in CITES 2000). Biomass estimates for Russian sturgeon are only available for 1993 and are lower than stellate and beluga (44.8 tonnes) (CITES 2000).

Fisheries regulations in the Black Sea [Bulgaria, Romania, Serbia and Ukraine (Russian sturgeon only)] are determined by individual countries including breeding season closures, gear restriction and minimum size requirements (CITES 2000). Black Sea and Sea of Azov nations communicate export quotas to the CITES Secretariat for approval and Black Sea nations have formed a regional management group (Black Sea Sturgeon Management Group) in fulfilment of CITES recommendations. CITES export quotas have been reduced since 2001, with the exception of sterlet quotas (Table 4). Illegal fishing is still problematic in both the Black Sea and the Sea of Azov, where illegal catch is estimated to be 19-29 times higher than the legal catch (Bacalbasa-Dobrovici 1997; in CITES 2000; Navodaru et al. 2001; Vaisman and Raymakers 2001).

Captive propagation and release is employed in the Black Sea and Sea of Azov (CITES 2000; Chebanov and Billard 2001; in Smith et al. 2002a). The Sea of Azov formerly had seven hatcheries releasing 39 million juveniles annually (7\% beluga, 43\% Russian, 49\% stellate), but many hatcheries are not functioning because of financial constraints and lack of broodstock (in Birstein 1997a; Vaisman and Raymakers 2001). Over 30 million individuals were released into the Don and Kuban rivers in 1999 and 2000 (Chebanov et al. 2002). Up to $100 \%$ of beluga sturgeon in the Sea of Azov are allegedly derived from hatcheries, compared with 80 to $95 \%$ of Russian and 60-98\% of stellate sturgeon (CITES 2000). Without tagging and monitoring programmes it is impossible to verify stocking success.

\section{Amur River basin}

The $4000 \mathrm{~km}$ Amur River basin forms the border between Russia and China for one-third of its length and harbours two endemic commercially exploited sturgeons, the kaluga and Amur sturgeon (Fig. 1;
Krykhtin and Svirskii 1997; Wei et al. 1997). Kaluga is a large, long-lived, late maturing, predominantly freshwater species while the Amur sturgeon is a smaller, strictly freshwater species maturing earlier than kaluga (Table 2; Fig. 2). Caviar produced from these species is referred to as kaluga (kaluga sturgeon) and osietra (Amur sturgeon).

Sturgeon catch in the Amur River peaked in 1891 (1195 tonnes; Table 2). In the last century, catch fluctuated between 100 tonnes to 400 tonnes annually on the Chinese side of the river and since the 1990s has been below 100 tonnes on the Russian side (Krykhtin and Svirskii 1997; Wei et al. 1997; CITES 2000; Zhuang et al. 2002). In 2003, 205 tonnes (120 tonnes China and 85 tonnes Russia) was caught overall, with 67 tonnes of Amur sturgeon and 138 tonnes of kaluga. Export quotas for both species have decreased since 2001 (Table 4).

As of 1997, population estimates for the four distinct populations of kaluga were as follows, with relatively few mature fish in any population: estuary (70 000), lower (40 000) and middle (30 000), upper Amur River (unavailable) (Krykhtin and Svirskii 1997). For Amur sturgeon, population estimates from the 1990s indicate about 3000 individuals in the estuarine populations, 95000 in the lower Amur, and 190000 in the middle Amur. Limits on catch in the 1970s resulted in population increases, but decreases, especially in the number of mature individuals, followed, in part, because of an illegal fishery in the lower Amur River (Krykhtin and Svirskii 1997). Catch records from the Chinese side of the Amur River indicate declines in both species, but accurate assessments are needed (Wei et al. 2004).

China and Russia manage Amur River populations under national regulations with export under CITES. Fishing for Amur sturgeon in China is regulated by gear, size limits, licensing, season and area (Wei et al. 1997, 2004; CITES 2000). Amur sturgeon fisheries have been banned in Russia since 1958 with catch for scientific purposes only, although Russia reportedly exceeds the scientific quota (Krykhtin and Svirskii 1997; CITES 2000). Implementation of regulations and illegal fishing are problematic and better joint management between Russia and China has been recommended (Krykhtin and Svirskii 1997; Wei et al. 1997, 2004; CITES 2000). Since 2001, CITES export quotas for kaluga and Amur sturgeon have decreased or remained constant (Table 4). 
Hatchery propagation and release of Amur sturgeon occurred in the Chinese side of the Amur River from 1988 to 1998 but operations have been jeopardized by financial constraints (Wei et al. 1997). Hatcheries on the Russian side of the Amur were not operational as of 2001 (Krykhtin and Svirskii 1997; Chebanov and Billard 2001). Amur sturgeon is an important aquaculture species in China accounting for most of national sturgeon farm production (CITES 2000; Zhuang et al. 2002; Wei et al. 2004). Kaluga is bred in China and released into the Amur River (Wei et al. 2004). No assessments of the success of release projects for Amur sturgeon or kaluga in China have been conducted (Wei et al. 2004).

\section{Siberian rivers}

Sturgeon fisheries in Siberian river systems target the Siberian sturgeon, a freshwater, potamodromous species (semi-anadromous forms are also recognized; Solovov and Vasila'v 1989; Solovov 1997 ) with a mid-range maturity age and spawning frequency (Tables 1 and 2; Figs 1 and 2). Catch within these fisheries peaked in the 1930 s with $79 \%$ of the catch from the Ob River (Table 2; Fig. 6d). Today, catch is $<10 \%$ of peak levels (Table 2; Figs 4 and 6d; Ruban 1997; CITES 2000). Compared with peak catch, by the 1990 s catch dropped by $99 \%$ in the Ob River, $96 \%$ in the Yenisey River and 95\% in the Lena River (Ruban 1997; CITES 2000).

Populations of Siberian sturgeon have declined across the species range (Afanasiev and Afanasieva 1996; Ruban and Akimova 2001). Forty per cent of spawning sites and $50 \%$ of wintering grounds in the $\mathrm{Ob}$ have been destroyed by hydroelectric stations (Ruban and Akimova 2001). The population in Lake Baikal may no longer reproduce naturally, sustained only by hatchery stocking (Afanasiev and Afanasieva 1996).

Commercial catch of Siberian sturgeon has been banned in the Yenisey River basin since 1998. Illegal harvest of sturgeons from Siberian Rivers is problematic, with catch reportedly in excess of official statistics (Ruban and Akimova 2001). With the exception of hatchery supplementation programmes in Lake Baikal, most captive programmes for Siberian sturgeon focus on aquaculture for commercial purposes. Siberian sturgeon is one of the most common captive-bred sturgeons, with farms in Europe, China, Japan and Uruguay (CITES
2000; Rosenthal and Hilge 2000; Gisbert and Williot 2002).

\section{Western North America}

Fisheries in western North American target white, and to a lesser extent, green sturgeon. White sturgeon inhabits estuaries, rivers and near shore environments of the Pacific coast from Alaska to Baja California, spawning in the Columbia-Snake River, Fraser River and Sacramento-San Joaquin River (Table 1; Fig. 1). The largest North American freshwater-dependent fish, the species is long lived and late maturing, existing as both anadromous and freshwater forms, the latter a result of dams (Table 2; Fig. 2). Green sturgeon range from northern Mexico to Alaska, spawning in the KlamathTrinity, Sacramento and Rogue River systems (Table 1; Fig. 1). An anadromous species, green sturgeon are small and mature relatively late (Table 2; Fig. 2). The green sturgeon was proposed for ESA listing in 2003, with a decision for further review by 2008 and the southern population segment is now a candidate for listing as threatened.

Overall, white sturgeon has supported larger fisheries than green sturgeon, with peak catches for white sturgeon in the late 1800s (Table 2). By 1902 the Sacramento-San Joaquin river fishery dropped by 95\% (Parsley and Beckman 1994; Williamson 2003). Catch in the Columbia River also dropped, rebounding in the late $1980 \mathrm{~s}$ (Fig. 6e). The Fraser River catch decreased $93 \%$ by 1905 and has not exceeded 15 tonnes since 1917 (Williamson 2003). Commercial fisheries in California and Canada have been closed since 1917 and 1994 respectively (Williamson 2003). US commercial fisheries in Oregon and Washington harvested close to 200 tonnes in 2002 and meat from the fishery has been exported under CITES (Table 4; Todd 1999; PacFin: http://www.psfmc.org/pacfin).

Only limited direct fisheries for green sturgeon have been recorded through history and at present, fisheries exist in the lower Columbia River, Klamath and Trinity rivers, Umpqua River, Sacramento-San Joaquin estuary and Willapa Bay and Grays Harbor (Moyle et al. 1995). Annual US commercial harvest between 1960 and 2002 peaked at 130 tonnes annually with recent catch below 10 tonnes (Todd 1999; EPIC 2001; Fig. 6f). In Canada, green sturgeon was historically targeted in the Fraser River but is now only caught as by-catch in coastal fisheries (EPIC 2001). 
Information on population size and structure is increasingly more available for white and green sturgeon. White sturgeon are abundant in the lower Columbia River where populations are considered stable (Hildebrand et al. 1999; Parsley et al. 2002). The Sacramento-San Joaquin estuary population declined from about 128000 individuals in 1984 to 27000 individuals in 1990 (Kohlhorst 1995). In Canada, the largest population is in the Fraser River system, with an estimated 47000 individuals in the lower River (Nelson et al. 2002). Canada's Nechako River and upper Columbia River populations are reportedly small and experiencing recruitment failure (Korman and Walters 2001). Two distinct populations of green sturgeon exist, northern (north of and including the Eel River) and southern (south of Eel River). Spawning populations were thought to be small (Musick et al. 2000), but research in the Rogue River (northern population segment) suggests populations are larger than previously thought (Erickson et al. 2002). Southern populations are more threatened due to dams (50 CFR 223 70 Fed. Reg. 17386 April 6, 2005). Green sturgeon populations in Canada are thought to be small (in EPIC 2001).

In the US, white and green sturgeon fisheries are managed by state and tribal agencies, using size, temporal and spatial limits restrictions (Rieman and Beamesderfer 1990; Beamesderfer and Farr 1997). Commercial fishing (trawl, gill net) is permitted in Oregon and Washington, although no directed green sturgeon commercial fisheries exist in these states. Since 1952, fisheries in California have been restricted to sport angling. Sports fishing is also permitted in Idaho, Oregon and Washington and regulated by strict size, season and bag limits: in Oregon and Washington, states that manage their fisheries cooperatively, an annual bag limit of 10 fish per fisherman is imposed. White sturgeon sport fisheries in Idaho are catch and release only. Commercial fisheries for green and white sturgeon are not active in Canada and all sport fisheries are catch and release. Canada's programmes in the Columbia, Fraser and Nechako river systems are actively monitoring and managing sturgeon populations.

White sturgeon in the US reaches of the Columbia River are monitored and managed through regular stock assessments, review and revision of fisheries regulations, and public awareness programmes (Rieman and Beamesderfer 1990; Beamesderfer and Farr 1997). Illegal poaching of white sturgeon is problematic in the US, with active smuggling rings reported as recently as May 2005 and white sturgeon caviar fraudulently sold as beluga and osetra (Cohen 1997; Enkoji 2005). Illegal harvest of green sturgeon is also suspected (EPIC 2001).

Commercial aquaculture and hatchery propagation (Kootenai River, upper Columbia River) programmes exist for white sturgeon with white sturgeon aquaculture caviar increasingly gaining prominence as high quality caviar (Logan et al. 1995; Ireland et al. 2002a,b; Williamson 2003).

\section{Anadromous species in eastern North America}

The eastern coast of North America is home to one commercially important species, the anadromous Atlantic sturgeon (A. o. oxyrinchus) (Table 1). The second largest species in North America, Atlantic sturgeon historically occurred in 34 river systems, and currently inhabits 32 systems, spawning in 14 (NMFS 1998b). Eighty to ninety per cent of historic Atlantic sturgeon landings occurred in the US with peak catch occurring in the late 1880 s and declining thereafter until fishery closure in 1998 (Table 2; Fig. 6g). US fishery closure is projected to last 41 years in order to protect 20 year classes of females in each spawning stock (NMFS 1998b). Canadian catch displayed a similar pattern to US catches in the late 1800 s and early 1900s, but increased in the late 1900s and a viable fishery still remains (Smith and Clugston 1997).

Comprehensive information on the abundance of Atlantic sturgeon is lacking (NMFS 1998b). There are six distinct population segments along the eastern seaboard, and US and Canadian stocks genetically distinct (Waldman et al. 1996; NMFS 1998b; Wirgin et al. 2000, 2002; King et al. 2001). Age-specific abundance estimates exist for a few US Rivers (e.g. Hudson and Delaware rivers) and restoration goals have been set for select rivers based on reconstructed historic population size estimates (Secor and Waldman 1999; Peterson et al. 2000; Armstrong and Hightower 2002; Secor 2002). Canada's St Lawrence River population is thought to be in good health (Caron et al. 2002; Hatin et al. 2002).

Commercial fisheries in Canada [St Lawrence River, Quebec (Canada's largest sturgeon fishery), St John River, Newfoundland] are managed through periodically revised licenses, quotas, and temporal and spatial closures (Caron and Tremblay 1999; Caron et al. 2002). Regulations specify a maximum 
size limit and large mesh size to protect the adult breeding population and a 60 tonnes annual limit in the St Lawrence fishery (NMFS 1998b; Caron et al. 2002; Trencia et al. 2002). Canadian maritime fisheries are managed through licensing but not quotas, with a sunset clause on commercial fishing licenses (Trencia et al. 2002; Williamson 2003). Canada has exported product from the fishery, mostly to the US (Table 4; Williamson 2003).

Atlantic sturgeon was one of the first sturgeons to be cultured in North America. Experimental restocking programmes have been conducted in the Hudson River and a tributary of the Chesapeake (NMFS 1998b; St. Pierre 1999; Peterson et al. 2000; Secor et al. 2000).

\section{Potamodromous species in inland and eastern North America}

Three commercially important potamodromous species of Acipenseriformes inhabit inland North America (shovelnose, paddlefish, lake sturgeon) (Table 1).

Shovelnose sturgeon inhabits the Missouri and Mississippi River basin with a range spanning 24 states (Keenlyne 1997). One of the smallest North American sturgeons, shovelnose sturgeon matures early and grows quickly (Table 2; Fig. 2). The caviar of this species is marketed as 'hackleback' roe. Catch of shovelnose sturgeon became important in the early 20th century but little historic catch data exist (Billard and Lecointre 2001; Quist et al. 2002; Williamson 2003). Currently, commercial harvest of shovelnose sturgeon is permitted in eight states (AZ, IL, IN, IA, KT, MO, TN, WI) with a 25tonnes annual harvest (Keenlyne 1997; Mosher 1999; Todd 1999; Williamson 2003). Harvest of this species in the Missouri River has increased in recent years (Quist et al. 2002).

The American paddlefish once inhabited 26 US states with a range including the Great Lakes and Canada but now exists in only 22 US states within the Mississippi River basin and Gulf coastal drainage. Paddlefish mature early and grow rapidly (Table 2; Fig. 2). Paddlefish caviar appears commercially as 'American' and 'American paddlefish' caviar. The commercial fishery for paddlefish caviar, particularly in the Mississippi River, increased after lake sturgeon became overfished with catches declining from the 1899 peak (Carlson and Bonislawsky 1981; Table 2; Fig. 6h). As of 2003, paddlefish was considered a sport fish in 15 states (AR, IL, IN, IA, KS, KY, MS, MO, MT, NE, ND, OH, OK, TN, SD), with late 1990 s catch estimates ranging from 0.2 to 20 tonnes per state annually (Mosher 1999; CITES 2000).

Lake sturgeon inhabits the US and Canada and is considered threatened in 20 US states and seven Canadian provinces (Table 1). The species is more plentiful in Canada, existing in Alberta, Saskatchewan, Manitoba, Ontario and Quebec, and is classified as rare over much of its US range, abundant only in Wisconsin (Ferguson and Duckworth 1997; Williamson 2003). Lake sturgeon matures late and reproduces relatively infrequently (Table 2; Fig. 2). Within 20 years of opening, the fishery for lake sturgeon in the Great Lakes reached peak harvest levels and subsequently collapsed (Baker and Borgeson 1999). Catches in Lake Erie fell 80\% between 1885 and 1895 (Ferguson and Duckworth 1997). In the upper Mississippi River, yield decreased by $97 \%$ (Knights et al. 2002). Currently, US lake sturgeon fishing is allowed only for sport and aboriginal harvest. Commercial catch in Canada (New Brunswick and Quebec) was 223 tonnes in 1997, 90\% of which occurred in the St Lawrence River (CITES 2000). The sport fishery in Canada is reportedly small (CITES 2000). Canada has exported lake sturgeon meat and caviar under CITES, with much of the meat imported by the US (Table 4; Williamson 2003).

Few published studies exist on population size and structure of these species and management is challenged by a lack of understanding of species status (Graham 1997; Keenlyne 1997; Runstrom et al. 2001; Williamson 2003). Information on shovelnose sturgeon is particularly scarce and studies conflict on species status, agreeing only that the species is stable in four states (IA, MT, NE, ND) and extirpated from $25 \%$ of its historic rivers and at least three states (Table 1; Keenlyne 1997; in Williamson 2003). Most states managing paddlefish lack basic demographic and catch information and studies conflict regarding paddlefish status (Graham 1997; Runstrom et al. 2001). Graham (1997) reported that as of 1997 paddlefish populations were stable in 14 states (AL, AR, IN, IA, KS, KY, LA, MN, MS, MO, MT, NE, OK, SD), increasing in three (TX, WV, WY), declining in two (IL, ND), of unknown status in three $(\mathrm{OH}, \mathrm{VA}, \mathrm{TN})$ and extirpated in four (NY, MD, NC, PA). A separate study indicated declines in five states (IA, MN, AR, MS, SD) and unknown status in six states (IL, MS, MO, 
MT, OH and WI) (in Runstrom et al. 2001). Lake sturgeon have been extirpated from at least four states (AL, AR, MS, WV) and reduced to $1 \%$ of their former abundance in the Great Lakes (Table 1; Peterson et al. 2002). Populations are structured on a watershed scale (Ferguson and Duckworth 1997) and population size estimates exist for some populations (e.g. Winnebago system; Threader and Brousseau 1986; Kempinger 1996; Bruch 1999; McLeod et al. 1999; Thomas and Haas 2002).

Little published information exists regarding shovelnose sturgeon fisheries management. Sport fishing regulations vary by state and include size limits and bag limits, but there are no uniform management standards (Keenlyne 1997; Mosher 1999). Overall the species is managed under state regulations similar to those for paddlefish (Williamson 2003).

Commercial catch of paddlefish is permitted in six states (AR, IL, KY, MS, MO, TN) with regulations varying by state and including limits on size and season (Graham 1997; Mosher 1999; Todd 1999; CITES 2000; Williamson 2003). Many states that permit commercial fishing do not require catch statistics reporting (CITES 2000; Williamson 2003). Most sport fisheries specify a daily bag limit of two individuals (normally without size limits), regulate the number of individuals harvested per year, and institute seasonal closures. Paddlefish is managed cooperatively among states in certain areas (e.g. MT/ND, NE/SD, Ohio River basin) and by Mississippi Interstate Cooperative Resource Agency (MICRA), a non-regulatory agency of 28 Mississippi river basin states (Williamson 2003). MICRA has initiated basin-wide tagging and assessment programmes and plans for a coordinated interstate management system. With no federal appropriations or management authority, MICRA has only limited capacity and influence (Williamson 2003). Poaching of paddlefish is problematic, especially in the Mississippi River and paddlefish caviar has been fraudulently sold as Russian caviar (CITES 2000; Williamson 2003).

Lake sturgeon commercial fisheries in the US waters in the Great Lakes were closed in 1977 (Baker and Borgeson 1999). Canadian commercial fisheries (Quebec, Ontario) are reportedly well managed, regulated by gear, size and season, with periodic closures based on stock estimates (Ferguson and Duckworth 1997; Nilo et al. 1997; McLeod et al. 1999; CITES 2000). Sport fishing for lake sturgeon is restricted to their northern range under strict regulation and periodic assessments (Ferguson and Duckworth 1997; Thuemler 1997; Baker and Borgeson 1999; Mosher 1999). Some sport fisheries allow catch and release only while others allow take under strict quotas: US sport fisheries are restricted to one fish per angler annually (Mosher 1999; CITES 2000). The sport fishery in the Winnebago system in Wisconsin is regarded as a model of management and recovery, implementing population monitoring, harvest assessments, habitat protection programmes, enforcement and public involvement (Bruch 1999; Secor et al. 2002). Population size estimates for Winnebago System lake sturgeon are available from the 1950s to the present and illustrate an increasing trend (Bruch 1999). Sturgeon management in Alberta, Canada, also uses an iterative process based on catch information (McLeod et al. 1999). However, a great deal of basic information (management units, key habitats, population sizes) is still lacking for the species (Knights et al. 2002).

Captive propagation and commercial aquaculture programmes for caviar production exist for paddlefish and lake sturgeon while only captive propagation programmes exist for shovelnose sturgeon (Williamson 2003). A 1998 study reported that 11 states had developed and/or were implementing restocking and re-introduction plans for shovelnose sturgeon. Restocking programmes for paddlefish exist in eight states and farms/hatcheries have been developed in four states and internationally (China, Russia, Moldavia, Romania; CITES 2000; Billard and Lecointre 2001). Artificial propagation techniques for paddlefish include reservoir ranching and monosex culturing (Carlson and Bonislawsky 1981; Mims and Shelton 1998; Onders et al. 2001). Lake sturgeon were re-introduced into Lake Superior and Oneida Lake, propagation programmes in Wisconsin have been ongoing since 1979, and additional programmes exist in five US states (MO, MN, NY, ND, WI) (Schram et al. 1999; CITES 2000; Jackson et al. 2002).

\section{Sturgeon fisheries of the world: observations and recommendations}

\section{Status of Acipensiformes populations and fisheries}

The comprehensive synopsis presented herein demonstrates that, with extremely few exceptions, sturgeon and paddlefish populations are imperilled across the globe and their long-term survival in the 
wild is in jeopardy (Table 1). Extinction of some populations (e.g. ship sturgeon, Aral Sea; beluga, Adriatic Sea) has already occurred, and 19 of the 27 species have experienced range contractions (Table 1). All extant species are acknowledged as threatened by CITES and only two species are considered Lower Risk by the IUCN (Table 1). Four of the nine species that occur in the US have populations listed under the US ESA, three of the non-listed US taxa have been petitioned for listing, and the non-native beluga sturgeon is also now listed as threatened (Table 1). Two of Canada's six species are considered of special concern, one as endangered and one as extirpated (Table 1).

Despite widespread recognition of their precarious status, commercial fisheries continue for 15 of the 27 species. The geographical focus of commercial fisheries production has shifted over time, moving to the Caspian region after North American and European fisheries were exhausted. Recent catches are at least $40 \%$ smaller than historic peak catch levels for all major sturgeon fisheries (Figs 3, 4 and 8 ), and are $<15 \%$ of historic levels for $70 \%$ of the populations examined (Fig. 8). Caspian Sea fisheries, although currently the most important on a global basis in absolute terms, are among the most depleted relative to former production levels, with present catches below $10 \%$ of historic peak landings (Fig. 8). Six of the fisheries examined here crashed within 7-20 years of opening, with catch levels at the end of the period ranging between 1\% and 10\% of peak catch values. Only a few depleted sturgeon populations currently protected by bans on fishing show signs of rebounding (e.g. Winnebago lake sturgeon, Fraser river white sturgeon); while other species thus protected have estimated recovery times exceeding 40 years (US Atlantic sturgeon, Canadian white sturgeon).

Clearly the life-history characteristics of sturgeons and paddlefishes, particularly their late onset of maturity and only periodic reproduction thereafter (Fig. 2) leave them ill-equipped to handle intensive harvest pressure, and make recovery following collapse at best a long-term proposition. These considerations, as well as their anadromous lifestyle and specific environmental requirements account for their extreme vulnerability, inevitably demanding a precautionary approach to their exploitation. While biological vulnerability is of vital importance, it is not the sole determinant of status or sustain-

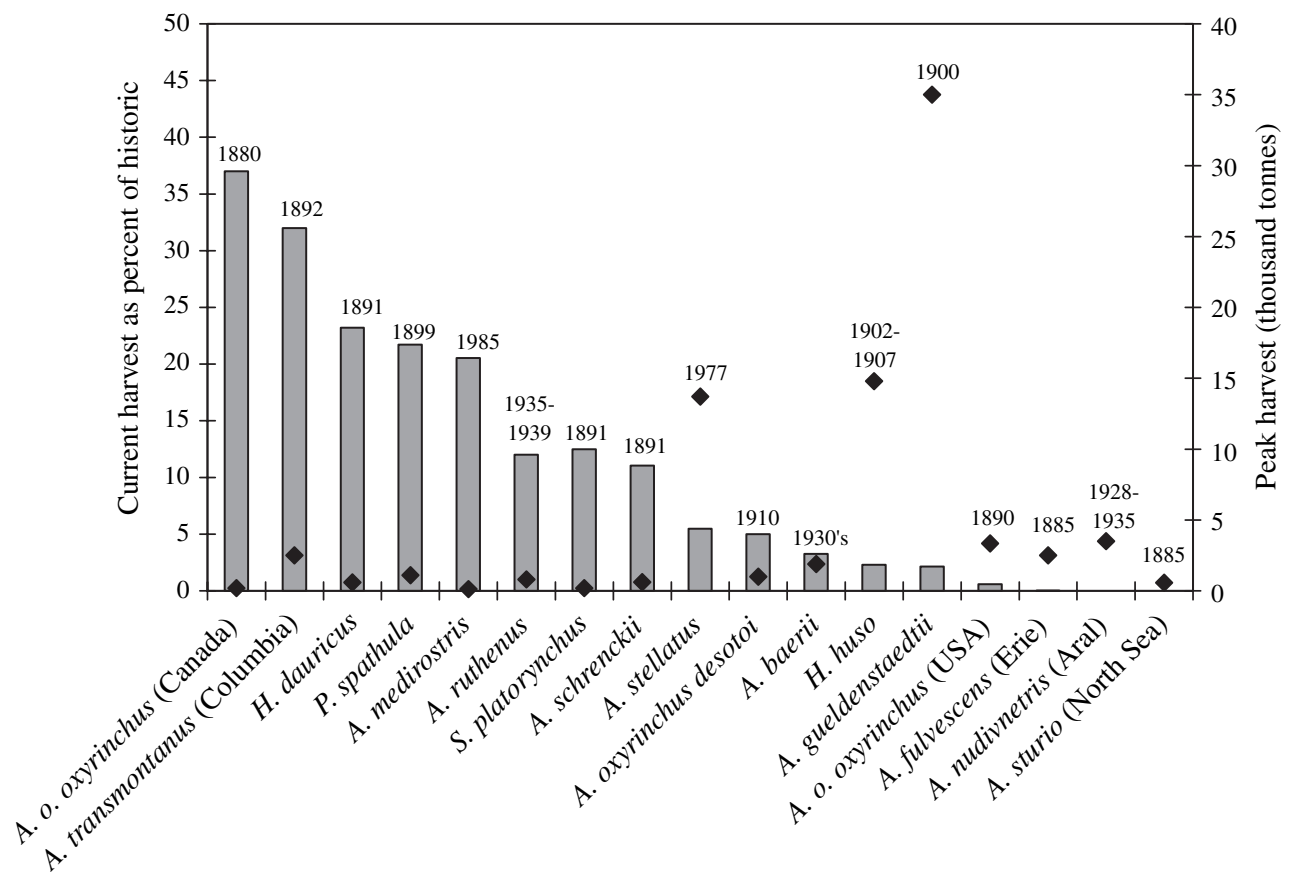

Figure 8 Historic and present species production. Bars indicate current production (or production recorded before fishery closure) as percentage of historic peak production. Diamonds represent peak production values and their respective dates. 
ability. For example, white sturgeon have the most delayed onset of maturity yet their status and prognosis is good relative to other species, whereas ship sturgeon have maturity and spawning periodicity near the median for the group yet are among the most endangered (Table 1; Fig. 2). Clearly current management effectiveness, restoration capacity, and habitat quality and quantity are important explanatory variables for differences among species and areas.

Our compilation of a simple 'report card' for a series of indicators critical to population persistence and restoration shows that, with only a few exceptions, current management practices, restoration capacity and habitat characteristics fall far short of that needed to provide a reasonably good prognosis for focal populations (Table 5). Of the 16 populations examined, only three had total scores exceeding $50 \%$ of the maximum, two had scores at or near $50 \%$ of maximum, and the remaining 11 species had scores at or below 25\% of maximum (Table 5). Overall, the North American populations fared substantially better than populations in other regions. Interestingly, the North American populations with the highest scores (white and Atlantic sturgeon) are those for which fishing is currently prohibited, although this was not an explicit criterion in the scoring. The major categories for which North American population scores surpassed those of Caspian, Black Sea, European and Asian populations were related to measures of management effectiveness (Table 5). In turn, management effectiveness appears closely related to political stability and the existence of effective intraregional cooperative agreements for populations covering more than one jurisdiction. Consistent with this notion is the finding that two of the North American populations with extremely low scores (shovelnose and paddlefish) are species whose populations span multiple states in the central US for which a regional agreement exists but lacks strength. The Caspian and Black Sea populations, with the lowest management effectiveness scores, are regions containing newly emerged independent states plagued by relatively high levels of poverty and corruption, the latter of which encompasses high rates of illegal fishing and trade. Clearly these are overarching, difficult problems that are beyond the scope of fisheries agencies to resolve, and are likely to remain problematic for a long time to come.

In terms of restoration capacity, it is encouraging that captive breeding technology is now available for all focal species, providing the potential for restoring populations with captive animals in the event that fishery and habitat pressures cannot be effectively controlled. The effectiveness of present and future restocking programmes is, however, uncertain given that measures to gauge their effectiveness (e.g. tagging and monitoring of recaptures) are generally lacking or inconsistently implemented (Table 5). It is also possible that restocking programmes may do more harm than good. This is of particular concern in areas where substantial amounts of spawning habitat and wild spawner abundance exist, and/or where genetic diversity of broodstock is not adequately maintained in captive breeding programmes. In fact, we found that genetic considerations are largely ignored for the vast majority of captive breeding programs examined (Table 5).

Identification, protection and restoration of critical habitat could be improved for all species. A particular challenge for sturgeon restoration is that, with the exception of a few European and Asian species the principal rivers of historic importance for spawning are no longer free flowing. Given the lack of effective dam bypass systems for sturgeon, elimination of existing dams is the only effective mechanism for meaningful habitat restoration.

\section{Recommendations on conservation priorities}

Given their imperilled status, extreme vulnerability, and poor management and restoration prognosis, recovery of the world's sturgeon and paddlefish populations is at best a precarious and long-term proposition. To ensure their future survival, priority should be given to those actions that have the best chance of stemming and reversing the decline of wild populations in the near term.

For Caspian Sea, Black Sea, Amur river and wild Siberian sturgeon populations, we recommend that urgent priority be given to reducing fishing pressure on wild populations through enforcement of existing international and domestic regulations and development of new, more restrictive measures. For the most threatened species, such as beluga and ship sturgeon, fisheries must be closed or harvest levels drastically reduced to allow rebuilding and to facilitate effective enforcement. Focus must shift towards preserving large, mature fish now rather than relying upon hatchery supplementation, future recruitment or habitat restoration. Lack of adequate wild broodstock at Azov and Caspian 


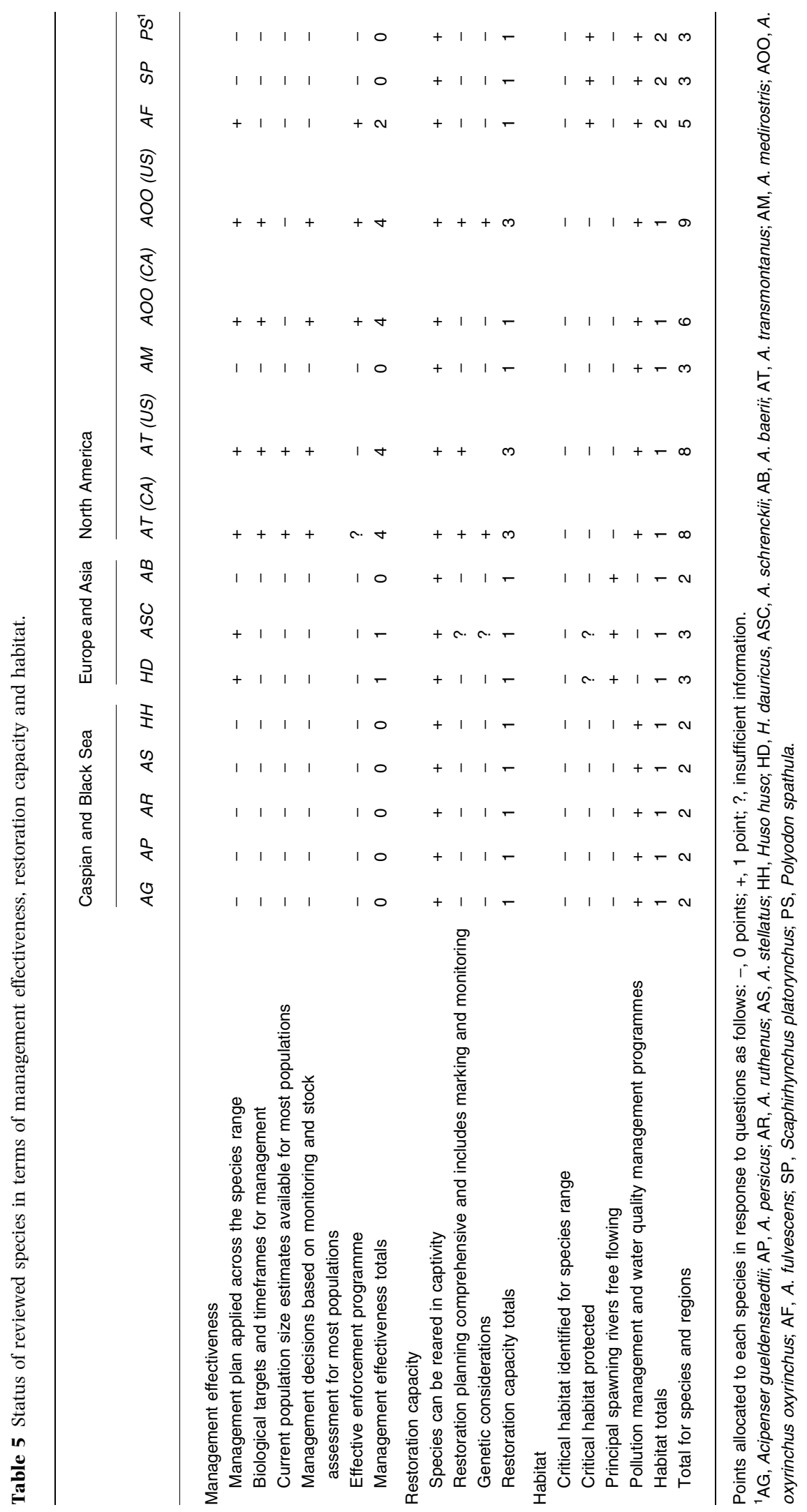


hatcheries and observed recruitment failures in Canadian white sturgeon populations underscore the priority of conserving existing mature fish over other options whose benefits are less reliable and less immediate.

The resolutions set forth by CITES should be more aggressively enforced. Although CITES listing has resulted in improved trade regulation, cooperative management of transboundary populations, and reduced export quotas, more could be accomplished (Raymakers 2002; Raymakers and Hoover 2002; Pikitch et al. 2004a,b). Non-zero trade quotas are routinely approved despite non-compliance with CITES resolution requirements, the absence of accurate population structure and abundance information, and illegal harvest and trade. While more research is needed to adequately monitor and manage sturgeon populations, adequate demographic information is already available, and essential measurements can be obtained using non-lethal sampling methods. Thus, in contrast to current practice, scientific quotas permitting fish kills should be banned.

For CITES to be most effective, the parties should adopt a precautionary approach with decisions on quotas considering uncertainty of population status, evidence of decline and rates of illegal fishing. In so doing, zero quotas will likely result for many species. Although the CITES parties have agreed to temporary trade bans in the past, the use of trade bans and zero quotas should be applied in all cases of noncompliance. The burden of proof should be shifted making compliance a prerequisite for non-zero quotas, creating an incentive for responsible management. An independent scientific authority should evaluate the impact of total harvest on wild populations, and establish and oversee standardized monitoring, assessment and quota-setting procedures for each watershed.

Conservation priorities for North American sturgeon and paddlefish populations vary among geographical regions. Shovelnose and paddlefish populations in inland North America are most in need of improvements in management effectiveness. Coordinated, interstate, transboundary management among states harbouring common populations should be strengthened and mandatory reporting of commercial and recreational landings should be instituted in all fisheries. Management effectiveness is relatively strong, and commercial fisheries are already prohibited for depleted coastal populations, so that recovery in these areas may be best facilitated through focused attention on habitat protection and restoration efforts and targeted research and monitoring programmes. Overall, although knowledge about some North American species has improved (Van Winkle et al. 2002 and references therein) basic demographic information is still lacking for some species (e.g. green sturgeon, shovelnose sturgeon, American paddlefish).

Only a few sturgeon fisheries are managed based upon frequent monitoring of population size, age and abundance and periodic stock assessment (Columbia River white sturgeon fishery, Canadian Atlantic sturgeon fishery, Canadian and Winnebago Lake sturgeon fisheries). Advances in modelling the response of sturgeon population to different management schemes are revealing whether sustainable sturgeon fisheries are indeed possible and quantifying acceptable levels of mortality (Rieman and Beamesderfer 1990; Boreman 1997; Root 2002; in Secor et al. 2002). The lessons learned must now guide management of other species. Consideration might be given to convening the international community of sturgeon and paddlefish conservationists to set guidelines for population monitoring, stock assessment and fisheries management programmes. Established as a textbook or manual for policymakers, managers and scientists, this effort would set a universal basis for acceptable management standards and could guide decision-making on commercial exploitation and trade.

Domestic legislation, management and education must also be strengthened globally. Many sturgeons and paddlefish populations are likely candidates for national protection and nations should move to review species within their jurisdiction. As fisheries in the Caspian decline, pressure may shift toward species not currently commercially valued and foresight is needed to review the adequacy of protection and management schemes now, especially for North American paddlefish and shovelnose sturgeon. Within the Caspian region, sturgeon conservation will require national commitments to fair, transparent, tightly regulated fisheries that embrace long-term sustainability goals. As corruption is problematic even within the agencies protecting sturgeons and many CIS nations have poor economic and unstable political outlooks, this will be difficult. Scientific entities in these nations are often closely tied to commercial interests, with profits from caviar and meat sales from scientific catch supporting hatcheries and science and scientific studies funded by fishing companies. As CIS 
nations transition, international efforts should focus on joint projects and training initiatives that build capacity and raise awareness among national scientists and that examine the long-term economic benefits of a sustained commercial fishery and the immediate alternatives to sturgeon fishing. Funding for such studies could be derived from an international trade tax and illegal trade and harvest penalties.

As natural populations, habitats and wild sources of caviar dwindle, captive rearing holds promise for an alternative source of caviar and wild population restoration. Captive populations are currently used for production of market-worthy aquaculture caviar and restoration of endangered populations (Speer et al. 2000; Mims 2001; Collins et al. 2002; Ireland et al. 2002a; Williamson 2003). Increased international trade in aquaculture products and live specimens and greater acceptance of aquaculture alternatives has ensued (Raymakers and Hoover 2002; see http://www.caviaremptor.org). Should aquaculture product continue to provide an alternative to wild caught product, pressure on wild populations could be relieved.

Both commercial aquaculture and hatchery propagation pose certain risks. Aquaculture can negatively affect the environment through disease introduction, escapement, pollution and use of wild fish for feed (Tsvetneko 1993). Farming non-native sturgeons can lead to non-native escape and threats to native species, as has happened in Europe and South America (Arndt et al. 2002; Bauer et al. 2002; Pikitch et al. 2004a,b). Commercial ventures can be conduits for illegal trade, increase market demand and illegal harvest pressure, and exacerbate enforcement problems (Czesny et al. 2000; Gessner et al. 2002; Williamson 2003). For critically endangered species like beluga, aquaculture can place further demands on deteriorating populations by removing broodstock from the wild (Pikitch et al. 2004 b). As such, aquaculture of sturgeons must proceed cautiously, embracing best management practices, use of native species, adequate labelling and control of products, and beneficial linkages to conservation efforts in the wild.

Hatchery propagation for re-introduction must also proceed cautiously. Genetic issues of inbreeding and genetic swamping must be considered. For anadromous species harbouring population structure corresponding to natal river, released individuals can stray to non-target rivers (Quattro et al. 2002; Smith et al. 2002a,b). Concentrated focus on captive rearing can divert attention from important management issues such as catch limitation and habitat restoration (Raymakers 2002; Williamson 2003). Recently developed restoration plans for sturgeon have made strides to consider these risks (e.g. Atlantic and shortnose sturgeon; NMFS 1998b; St. Pierre 1999; reviewed in Williamson 2003), and should guide restoration planning for other species, including Sea of Azov beluga and Lake Baikal Siberian sturgeon. Overall, re-introduction should be a used for only the most endangered populations with little hope of natural recovery, in cases where fishing pressure has been relieved, and with the objective of restoring the population and using and ecosystem-based approach (Pikitch et al. 2004a,b).

Merging aquaculture and captive propagation projects could prove beneficial. As captive populations harbour insufficient genetic diversity, are of mixed stock origin, or consist of hybrids, they generally cannot be used for restoration projects (Williot et al. 2001). Encouraging the development of joint programmes that produce commercial products using captive populations also suitable for restoration programmes could benefit species for which aquaculture but not restoration programmes exist (Siberian sturgeon) and for which commercial products are highly valued and captive propagation is an important conservation tool (Caspian species). At the very least, all aquaculture production facilities should be required to contribute to in situ conservation or participate in captive gene exchange programmes. Establishment of these types of programmes in the Caspian region could provide alternative livelihood options to commercial fishermen and reduce pressure on wild populations.

Technological improvements are needed to develop methods to mark/tag released individuals, distinguish aquaculture from wild-caught products, and cryo-banking. Methods to quantify recruitment of hatchery-released individuals are needed, especially for fisheries where restocking is heavily used, quotas are established based upon the number of hatchery fish released, and/or stock assessment models consider the contribution of hatchery fish. Lastly, much of the research on culture, tagging, monitoring and enhancing the survivability of released individuals is occurring in areas and for species not currently under the greatest harvest pressure making knowledge transfer a priority.

Programmes that inform the public about sturgeon conservation, such as through participatory 
research and media and outreach campaigns, exist in the US, Canada and Europe, and can inspire public action to change domestic and international policy. Consumer awareness campaigns such as Caviar Emptor have affected consumer and retailer behaviour towards beluga and Caspian caviar, stimulated the development of high-quality alternatives and brought greater international attention to the plight of sturgeon. Programmes that educate and encourage consumers to purchase sturgeon products only from legal, environmentally sound and sustainable fisheries should continue. Most importantly, public education and awareness campaigns are needed in the Caspian region to inspire fisheries reform. While farmed caviar and sturgeon meat production has been increasing, the rate of increase is not likely to keep pace with the reduction in wild fishery production in the near term, and meeting global demand for caviar may become increasingly more difficult. Thus, efforts to shift demand away from the most highly endangered species and to reduce overall demand are likely to be important components of a global sturgeon conservation strategy.

\section{Acknowledgements}

Elizabeth Babcock, Vadim Birstein, Shannon Crownover, Will Ferretti, Lisa Speer, Vikki Spruill, Sunny $\mathrm{Wu}$ and manuscript referees contributed to this manuscript through useful comments and discussions. This work was accomplished through contributions from the David and Lucile Packard Foundation, The Oak Foundation, Pew Institute for Ocean Science and Pew Charitable Trusts, and the Wildlife Conservation Society.

\section{References}

Afanasiev, G.A. and Afanasieva, B.G. (1996) Status of resources and natural reproduction of the Baikal sturgeon. Rybovodstvo i Rybolovstvo 2, 6-7.

Agence France Presse (2004) Nearly 80 percent of Russia's fish trade illegal: Putin. June 23, 2004.

Altuf'ev, Y. (1997) Morphofunctional abnormalities in the organs and tissues of the Caspian Sea sturgeons caused by ecological changes. In: Sturgeon Stocks and Caviar Trade Workshop (Proceedings of the Sturgeon Stocks and Caviar Trade Workshop, Bonn, 9 October-10 October, 1995). V.J. Birstein, A. Bauer and A. Kaiser-Pohlmann, eds. IUCN, Gland, Cambridge, Bonn, pp. 21-28.

Altukhov, Y.P. and Evsyukov, A.N. (2001) Juvenile overproduction at fish hatcheries may explain the degradation of the Volga stock of the Russian sturgeon. Doklady Biological Sciences 380, 454-456.

Anders, P., Richards, D.L. and Powell, M.S. (2002) The first endangered white sturgeon population; repercussions in an altered large river-floodplain ecosystem. In: Biology, Management and Protection of North American Sturgeon (eds W. Van Winkle, P.J. Anders, D.H. Secor and D.A. Dixon). American Fisheries Society, Bethesda, pp. 67-82.

Arai, T. and Miyazaki, N. (2001) Use of otolith microchemistry to estimate the migratory history of the Russian sturgeon, Acipenser gueldenstaedtii. Journal of Marine Biological Association UK 81, 709-710.

Armstrong, J. and Hightower, J.E. (2002) Potential for restoration of the Roanoke River population of Atlantic sturgeon. Journal of Applied Ichthyology 18, 475480.

Arndt, G-M., Gessner, J. and Raymakers, C. (2002) Trends in farming, trade and occurrence of native and exotic sturgeons in natural habitats in Central and Western Europe. Journal of Applied Ichthyology 18, 444-448.

Artyukhin, E.N. (1997) The current status of commercial sturgeon species in the Volga River-Caspian Sea Basin. In: Sturgeon Stocks and Caviar Trade Workshop (Proceedings of the Sturgeon Stocks and Caviar Trade Workshop, Bonn, 9 October-10 October, 1995). V.J. Birstein, A. Bauer and A. Kaiser-Pohlmann, eds. IUCN, Gland, Cambridge, Bonn, pp. 9-12.

Artyukhin, E.N. and Andronov, A.E. (1990) A morphological study of the green sturgeon Acipenser medirostris (Chondrostei, Acipenseridae), from the Tumnin (Datta) River and some aspects of the ecology and zoogeography of Acipenseridae. Journal of Ichthyology 30, 11-21.

Artyukhin, E.N. and Zarkua, Z.G. (1986) Taxonomic status of sturgeon of the Rioni River (Black Sea basin). Voprosy Ikhtiologii 26, 61-67 (in Russian; English translation: Journal of Ichthyology 26, 29-36).

Bacalbasa-Dobrovici, N. (1997) Endangered migratory sturgeons of the lower Danube River and its delta. Environmental Biology of Fishes 48, 201-207.

Baker, E.A. and Borgeson, D.J. (1999) Lake Sturgeon abundance and harvest in Black Lake, Michigan, 1975 1999. North American Journal of Fisheries Management 19, 1080-1088.

Bauer, A. (1997) Overview: economical importance and conservation of sturgeons. In: Sturgeon Stocks and Caviar Trade Workshop (Proceedings of the Sturgeon Stocks and Caviar Trade Workshop, Bonn, 9 October-10 October, 1995). V.J. Birstein, A. Bauer and A. Kaiser-Pohlmann, eds. IUCN, Gland, Cambridge, Bonn, pp. 1-6.

Bauer, O.N., Pugachev, O.N. and Voronin, V.N. (2002) Study of parasites and diseases of sturgeons in Russia: a review. Journal of Applied Ichthyology 18, 420-429.

Beamesderfer, R.C.P. and Farr, R.A. (1997) Alternatives for the protection and restoration of sturgeons and their habitat. In: Sturgeon Biodiversity and Conservation (eds 
V.J. Birstein, J.R. Waldman and W.E. Bemis). Kluwer Academic Publishers, Dordrecht, pp. 407-417.

Bemis, W.E. and Kynard, B. (1997) Sturgeon rivers: an introduction to Acipenseriformes biogeography and life history. In: Sturgeon Biodiversity and Conservation (eds V.J. Birstein, J.R. Waldman and W.E. Bemis). Kluwer Academic Publishers, Dordrecht, pp. 167-183.

Bemis, W.E., Findeis, E. and Grande, L. (1997) An overview of Acipenseriformes. In: Sturgeon Biodiversity and Conservation (eds V.J. Birstein, J.R. Waldman and W.E. Bemis). Kluwer Academic Publishers, Dordrecht, pp. 25-71.

Berg, L.S. (1934) Acipenser guldenstadti persicus, a sturgeon from the South Caspian Sea. Annual Magazine of Natural History 10, 317-318.

Berg, L.S. (1940) Classification of fishes both recent and fossil. Trudy Zoologicheskogo Instituta 5, 85-517 (in Russian).

Berg, L.S. (1948) The Freshwater Fishes of the USSR and Adjacent Countries, 4th edn, Part 1. Akademiya Nauk USSR, Moscow, Lenningrad (in Russian, English translation published by Israel Program for Scientific Translations, Jerusalem).

Bickham, J.W., Rowe, G.T., Palatnikov, G. et al. (1998) Acute and genotoxic effects of Baku Harbor sediment on Russian sturgeon, Acipenser gueldenstaedtii. Bulletin of Environmental Conservation and Toxicology 61, 512-519.

Billard, R. and Lecointre, G. (2001) Biology and conservation of sturgeon and paddlefish. Reviews in Fish Biology and Fisheries 10, 355-392.

Birstein, V.J. (1993) Sturgeons and paddlefishes: threatened fishes in need of conservation. Conservation Biology 7. 773-787.

Birstein, V.J. (1996) Sturgeons in the lower Danube: a trip to Romania. Sturgeon Quarterly 4, 10-11.

Birstein, V.J. (1997a) Concluding remarks: the current status of sturgeons, threats to their survival, the caviar trade and the international efforts needed to save them. In: Sturgeon Stocks and Caviar Trade Workshop (Proceedings of the Sturgeon Stocks and Caviar Trade Workshop, Bonn, 9 October-10 October, 1995). V.J. Birstein, A. Bauer and A. Kaiser-Pohlmann, eds. IUCN, Gland, Cambridge, Bonn, pp. 71-88.

Birstein, V.J. (1997b) Threatened species of the world: Pseudoscaphirhynchus spp. (Acipenseridae). Environmental Biology of Fishes 48, 381-383.

Birstein, V.J. and Bemis, W.E. (1997) How many species are there within the genus Acipenser? In: Sturgeon Biodiversity and Conservation (eds V.J. Birstein, J.R. Waldman and W.E. Bemis). Kluwer Academic Publishers, Dordrecht, pp. 157-163.

Birstein, V.J. and DeSalle, R. (1998) Molecular phylogeny of Acipenserinae. Molecular Phylogenetics and Evolution 9, 141-155.

Birstein, V.J. and Doukakis, P. (2002) Molecular identification of sturgeon species: science, bureaucracy, and the impacts of environmental agreements. Monitoring Migratory Animals, Bonn Convention ??, 47-63.

Birstein, V.J., Bemis, W.E. and Waldman, J.R. (1997a) The threatened status of acipenseriform fishes: a summary. In: Sturgeon Biodiversity and Conservation (eds V.J. Birstein, J.R. Waldman and W.E. Bemis). Kluwer Academic Publishers, Dordrecht, pp. 427-435.

Birstein, V.J., Hanner, R. and DeSalle, R. (1997b) Phylogeny of the Acipenseriformes: cytogenetic and molecular approaches. In: Sturgeon Biodiversity and Conservation (eds V.J. Birstein, J.R. Waldman and W.E. Bemis). Kluwer Academic Publishers, Dordrecht, pp. 127-155.

Birstein, V.J., Waldman, J.R., Bemis, W.E. (eds) (1997c) Sturgeon Biodiversity and Conservation. Kluwer Academic Publishers, Dordrecht, 444 pp.

Birstein, V.J., Doukakis, P., Sorkin, B. and DeSalle, R. (1998) Population aggregation analysis of caviar producing species of sturgeons and implications for diagnosis of black caviar. Conservation Biology 12, 766-775.

Birstein, V.J., Doukakis, P. and DeSalle, R. (2000) Polyphyly of mtDNA lineages in the Russian sturgeon, Acipenser gueldenstaedtii: forensic and evolutionary implications. Conservation Genetics 1, 81-88.

Birstein, V.J., Doukakis, P. and DeSalle, R. (2002) Molecular phylogeny of Acipenseridae: non-monophyly of Scaphirhynchinae. Copeia 2002, 287-301.

Boreman, J. (1997) Sensitivity of North American sturgeons and paddlefish to fishing mortality. In: Sturgeon Biodiversity and Conservation (eds V.J. Birstein, J.R. Waldman and W.E. Bemis). Kluwer Academic Publishers, Dordrecht, pp. 399-405.

Bramblett, R.G. and White, R.G. (2001) Habitat use and movements of pallid and shovelnose sturgeon in the Yellowstone and Missouri Rivers in Montana and North Dakota. Transactions of the American Fisheries Society 130, 1006-1025.

Bruch, R. (1999) Management of lake sturgeon on the Winnebago system-long term impacts of harvest and regulations on population structure. Journal of Applied Ichthyology 15, 142-152.

Campton, D., Bass, A.L., Chapman, F.A. and Bowen, B.W. (2000) Genetic distinction of pallid, shovelnose and Alabama sturgeon: emerging species and the US Endangered Species Act. Conservation Genetics 1, 17-32.

Carlson, D.M. and Bonislawsky, P.S. (1981) The paddlefish (Polyodon spathula) fisheries of the midwestern United States. Fisheries 6, 17-27.

Caron, F. and Tremblay, S. (1999) Structure and management of an exploited population of Atlantic sturgeon (Acipenser oxyrinchus) in the St. Lawrence Estuary, Quebec, Canada. Journal of Applied Ichthyology 15, 153-156.

Caron, F., Hatin, D. and Fortin, R. (2002) Biological characteristics of adult Atlantic sturgeon (Acipenser oxyrinchus) in the St Lawrence River estuary and the 
effectiveness of management rules. Journal of Applied Ichthyology 18, 580-585.

Ceapa, C., Williot, P. and Bacalbasa-Dobrovici, N. (2002) Present state and perspective of stellate sturgeon brood fish in the Romanian part of the Danube. International Review of Hyrdrobiology 87, 507-513.

Chebanov, M. and Billard, R. (2001) The culture of sturgeons in Russia: production of juveniles for stocking and meat for human consumption. Aquatic Living Resources 14, 375-381.

Chebanov, M., Karnaukhov, G.I., Galich, E.V. and Chmir, Y.N. (2002) Hatchery stock enhancement and conservation of sturgeon, with an emphasis on the Azov Sea populations. Journal of Applied Ichthyology 18, 463-469.

Choudhury, A. and Dick, T.A. (1998) The historical biogeography of sturgeons (Osteichthyes: Acipenseridae): a synthesis of phylogenetics, paleontology and palaeogeography. Journal of Biogeography 25, 623-640. CITES (2000) Document AC.16.7.2. 16th meeting of the CITES Animals Committee, Shepherdstown, 11-15 December 2000.

Cohen, A. (1997) Sturgeon poaching and black market caviar: a case study. In: Sturgeon Biodiversity and Conservation (eds V.J. Birstein, J.R. Waldman and W.E. Bemis). Kluwer Academic Publishers, Dordrecht, pp. 423-426.

Collins, M.R., Post, W.C., Russ, D.C. and Smith, T.I.J. (2002) Habitat use and movements of juvenile shortnose sturgeon in the Savannah River, Georgia-South Carolina. Transactions of the American Fisheries Society 131, 975-979.

Czesny, S., Dabrowski, K., Christensen, J.E., Van Eenennaam, J. and Doroshov, S. (2000) Discrimination of wild and domestic origin of sturgeon ova based on lipids and fatty acid analysis. Aquaculture 189, 145-153.

Daskalov, G.M. (2002) Overfishing drives a trophic cascade in the Black Sea. Marine Ecology Progress Series 225, 53-63.

De Meulenaer, T. and Raymakers, C. (1996) Sturgeons of the Caspian Sea and Investigation of the International Trade in Caviar. TRAFFIC International, Cambridge.

Debus, L. (1997) Sturgeons in Europe and causes for their decline. In: Sturgeon Stocks and Caviar Trade Workshop (Proceedings of the Sturgeon Stocks and Caviar Trade Workshop, Bonn, 9 October-10 October, 1995). V.J. Birstein, A. Bauer and A. Kaiser-Pohlmann, eds. IUCN, Gland, Cambridge, Bonn, pp. 55-68.

DeSalle, R. and Birstein, V.J. (1996) PCR identification of black caviar. Nature 381, 197-198.

Dettlaff, T.A., Ginsburg, A.S. and Schmalhausen, O.I. (1993) Sturgeon Fishes: Developmental Biology and Aquaculture. Springer Verlag, New York.

Doukakis, P., Birstein, V.J. and DeSalle, R. (1999) Molecular genetic analysis among subspecies of two Eurasian sturgeon species, Acipenser baerii and A. stellatus. Molecular Ecology 8(S12), 117-129.
Doukakis, P., Pikitch, E.K., Baimukhanov, M., Sissengaliyeva, G., Melnikov, V., Yerbulekov, S. and Crownover, S. (2004) Caviar and conservation. Caucasus Environment 6, 21-23.

Dubina, V. and Kozlitina, S.V. (2000) Water resources management of the southern rivers of Russia with reference to fisheries requirements. Fisheries Management and Ecology 7, 157-165.

Dumont, H. (1995) Ecocide in the Caspian Sea. Nature 377, 673-674.

Enkoji, M.S. (2005) Alleged sturgeon ring landed. The Sacramento Bee May 6.

EPIC (2001) Petition to list the North American green sturgeon (Acipenser medirostris) as an endangered or threatened species under the Endangered Species Act. Environment Protection Information Center, Center for Biological Diversity, Waterkeepers Northern California, Gabreville, CA, USA.

Epifano, J.M., Koppelman, J.B., Nedbal, M.A. and Philip, D.P. (1996) Geographic Variation of paddlefish allozymes and mitochondrial DNA. Transactions of the American Fisheries Society 125, 546-561.

Erickson, D., North, J.A., Hightower, J.E., Weber, J. and Lauck, L. (2002) Movement and habitat use of green sturgeon Acipenser medirostris in the Rogue River, Oregon, USA. Journal of Applied Ichthyology 18, 565569.

Everett, S.R., Scarnecchia, D.L., Power, G.J. and Williams, C.J. (2003) Comparison of age and growth of shovelnose sturgeon in the Missouri and Yellowstone Rivers. North American Journal of Fisheries Management 23, 230-240.

Ferguson, M.M. and Duckworth, G.A. (1997) The status and distribution of lake sturgeon, Acipenser fulvescens, in the Canadian provinces of Manitoba, Ontario and Quebec: a genetic perspective. In: Sturgeon Biodiversity and Conservation (eds V.J. Birstein, J.R. Waldman and W.E. Bemis). Kluwer Academic Publishers, Dordrecht, pp. 299-309.

Findeis, E.K. (1997) Osteology and phylogenetic relationships of recent sturgeons. In: Sturgeon Biodiversity and Conservation (eds V.J. Birstein, J.R. Waldman and W.E. Bemis). Kluwer Academic Publishers, Dordrecht, pp. 73-106.

Fontana, F., Tagliavini, J. and Congiu, L. (2001) Sturgeon genetics and cytogenetics: recent advancements and perspectives. Genetica 111, 359-373.

Friedl, G. and Wüest, A. (2002) Disrupting biogeochemical cycles - consequences of damming. Aquatic Science 64, $55-65$.

Gardiner, B.G. (1984) Sturgeons as living fossils. In: Living Fossils (eds N. Eldredge and S.M. Stanley). SpringerVerlag, New York, pp. 148-152.

Gessner, J., Wirth, M., Kirschbaum, F., Kruger, A. and Patriche, N. (2002) Caviar composition in wild and cultured sturgeons - impact of food sources on fatty acid 
composition and contaminant load. Journal of Applied Ichthyology 18, 665-672.

Ginsberg, J. (2002) CITES at 30, or 40. Conservation Biology 16, 1184-1190.

Gisbert, E. and Williot, P. (2002) Advances in the larval rearing of Siberian sturgeon. Journal of Fish Biology $\mathbf{6 0}$, 1071-1092.

Gorbunenko, P., Trombitski, I. and Sharapanovskaya, T. (1997) Threats to Dniester River biodiversity. Endangered Ecosystems 11, 17.

Graham, K. (1997) Contemporary status of the North American paddlefish, Polyodon spathula. In: Sturgeon Biodiversity and Conservation (eds V.J. Birstein, J.R. Waldman and W.E. Bemis). Kluwer Academic Publishers, Dordrecht, pp. 278-289.

Grande, L. and Bemis, W.E. (1996) Interrelationships of Acipenseriformes, with comments on 'Chondrostei'. In: Interrelationships of Fishes. (eds M.L., Staisny, J.L.R., Parenti and G.D., Johnson). Academic Press, San Diego, CA, pp. 85-115.

Gross, M.R., Repka, J., Robertson, C.T., Secor, D.H. and Van Winkle, W. (2002) Sturgeon conservation: Insights from elasticity analysis. In: Biology, Management and Protection of North American Sturgeon (eds W. Van Winkle, P.J. Anders, D.H. Secor and D.A. Dixon). American Fisheries Society, Bethesda, MD, pp. 13-30.

Grunwald, C., Stabile, J., Waldman, J.R., Gross, R. and Wirgin, I. (2002) Population genetics of shortnose sturgeon Acipenser brevirostrum based on mitochondrial DNA control region sequences. Molecular Ecology 11, 1885-1898.

Gucu, A.C. (2002) Can overfishing be responsible for the successful establishment of Mnemiopsis leidyi in the Black Sea? Estuarine, Coastal and Shelf Science 54, 439-451.

Hart, D.D., Johnson, T.E., Bushaw-Newton, K.L. et al. (2002) Dam removal: challenges and opportunities for ecological research and river restoration. Bioscience $\mathbf{5 2}$, 669-682.

Hatin, D., Fortin, R. and Caron, F. (2002) Movements and aggregation areas of adult Atlantic sturgeon (Acipenser oxyrinchus) in the St Lawrence River estuary, Quebec, Canada. Journal of Applied Ichthyology 18, 586-594.

Hensel, K. and Holcik, J. (1997) Past and current status of sturgeons in the upper and middle Danube River. In: Sturgeon Biodiversity and Conservation (eds V.J. Birstein, J.R. Waldman and W.E. Bemis). Kluwer Academic Publishers, Dordrecht, pp. 185-200.

Hildebrand, L., McLeod, C. and McKenzie, S. (1999) Status and management of white sturgeon in the Columbia River in British Columbia, Canada: an overview. Journal of Applied Ichthyology 15, 164-172.

Hoover, C. (1998) Import and export of sturgeon and paddlefish in the United States. In: Symposium on the Harvest, Trade and Conservation of North American Paddlefish and Sturgeon (Proceedings of the Symposium on the Harvest, Trade, and Conservation of North
American Paddlefish and Sturgeon, Chattanooga, Tennessee, 7 May-8 May, 1998). D.F. Williamson, G.W. Benz and C.M. Hoover, eds. TRAFFIC North America/World Wildlife Fund, Washington, DC, pp. 162-170.

Ireland, S., Anders, P.J. and Siple, J.T. (2002a) Conservation aquaculture: an adaptive approach to prevent extinction of an endangered white sturgeon population. In: Biology, Management and Protection of North American Sturgeon (eds W., Van Winkle, P.J., Anders, D.H., Secor and D.A., Dixon). American Fisheries Society, Bethesda, MD, pp. 211-222.

Ireland, S., Beamesderfer, R.C.P., Paragamian, V.L., Wakkinen, V.D. and Siple, J.T. (2002b) Success of hatcheryreared juvenile white sturgeon (Acipenser transmontanus) following release in the Kootenai River, Idaho, USA. Journal of Applied Ichthyology 18, 642-650.

ITAR-TASS News Agency (2004) Proceeds from Russian sturgeon poaching on a par with drugs sales. ITAR-TASS News Agency, Moscow in Russian 08:15 GMT 24 June 04.

Jackson, J., Van De Valk, A.J., Brooking, T.E., Van Keeken, O.A. and Rudstam, L.G. (2002) Growth and feeding dynamics of lake sturgeon, Acipenser fulvescens, in Oneida Lake, New York: results from the first five years of a restoration program. Journal of Ichthyology 18, 439443.

Jennings, C. and Zigler, S.J. (2000) Ecology and biology of paddlefish in North America: historical perspectives, management approaches and research priorities. Reviews in Fish Biology and Fisheries 10, 167-181.

Kallemeyn, L. (1983) Status of the pallid sturgeon, Scaphirhynchus albus. Fisheries 8, 3-9.

Keenlyne, K. (1997) Life history and status of the shovelnose sturgeon, Scaphirhynchus platorynchus. In: Sturgeon Biodiversity and Conservation (eds V.J. Birstein, J.R. Waldman and W.E. Bemis). Kluwer Academic Publishers, Dordrecht, pp. 291-298.

Kempinger, J. (1996) Habitat, growth and food of young lake sturgeons in the Lake Winnebago system, Wisconsin. North American Journal of Fisheries Management 16, 102-114

Khodorevskaya, R.P. (1999) Formation of commercial stock of Huso huso in the Volga-Caspian region by hatchery reproduction. Journal of Ichthyology 39, 807810.

Khodorevskaya, R.P. and Krasikov, Y.V. (1999) Sturgeon abundance and distribution in the Caspian Sea. Journal of Applied Ichthyology 15, 106-113.

Khodorevskaya, R.P., Dovgopol, G.F. and Zhuravleva, O.L. (1995) Formation of commercial sturgeon (Acipenseridae) stocks. In: International Symposium on Sturgeons (Proceedings of the International Symposium on Sturgeons, Moscow, 6 September-11 September, 1993). (A.D. Gershanovich and T.I.J. Smith, eds). VNIRO Publishing, Moscow, pp. 137-150. 
Khodorevskaya, R.P., Dovgopol, G.F., Zhuravleva, O.L. and Vlasenko, A.D. (1997) Present status of commercial stocks of sturgeons in the Caspian Sea basin. In: Sturgeon Biodiversity and Conservation (eds V.J. Birstein, J.R. Waldman and W.E. Bemis). Kluwer Academic Publishers, Dordrecht, pp. 209-219.

Khodorevskaya, R.P., Krasikov, E.V., Dovgopol, G.F. and Zhuravleva, O.L. (2000) Formation of the stock of Caspian Acipenserids under present-day conditions. Journal of Ichthyology 40, 602-609.

Khodorevskaya, R.P., Krasikov, E.V., Fedin, A.A., Fedorov, V.A. and Shvedov, V.V. (2002) Abundance and distribution of the Beluga Huso huso in the Caspian Sea. Journal of Ichthyology 42, 51-58.

King, T.L., Lubinski, B.A. and Spidle, A.P. (2001) Microsatellite DNA variation in Atlantic sturgeon (Acipenser oxyrinchus oxyrinchus) and cross-species amplification in the Acipenseridae. Conservation Genetics 2, 103-119.

Knights, B.C., Vallazza, J.M., Zigler, S.J. and Dewey, M.R. (2002) Habitat and movement of lake sturgeon in the upper Mississippi river system, USA. Transactions of the American Fisheries Society 131, 507-522.

Kohlhorst, D.W. (1995) Use of a mathematical model as a management tool to evaluate sport angling regulations for white sturgeon, Acipenser transmontanus, in the Sacramento-San Joaquin estuary, California. In: International Symposium on Sturgeons (Proceedings of the International Symposium on Sturgeons, Moscow, 6 September-11 September, 1993). A.D. Gershanovich and T.I.J. Smith, eds. VNIRO Publishing, Moscow, pp. 239-249.

Korman, J. and Walters, C. (2001) Nechako River White Sturgeon Recovery Planning. Summary of Stock Assessment and Oct. 2-3, 2000 Workshop, BC Fisheries Victoria, BC. Available at: http://wlapwww.gov.bc.ca/ nor/fish/sturgeon/KormanReport.pdf.

Krykhtin, M.L. and Svirskii, V.G. (1997) Sturgeon catch and the current status of sturgeon stocks in the Amur River. In: Sturgeon Stocks and Caviar Trade Workshop (Proceedings of the Sturgeon Stocks and Caviar Trade Workshop, Bonn, 9 October-10 October, 1995). V.J. Birstein, A. Bauer and A. Kaiser-Pohlmann, eds. IUCN, Gland, Cambridge, Bonn, pp. 29-34.

Kuznetsov, V.A. (2000) Size and age structure, growth, and sexual maturation of Acipenser ruthenus in the Kuibyshev Reservoir. Journal of Ichthyology 40, 182190.

Kynard, B. (1997) Life history, latitudinal patterns and status of the shortnose sturgeon, Acipenser brevirostrum. In: Sturgeon Biodiversity and Conservation (eds V.J. Birstein, J.R. Waldman and W.E. Bemis). Kluwer Academic Publishers, Dordrecht, pp. 319-334.

Kynard, B. and Horgan, M. (2002) Ontogenetic behavior and migration of Atlantic sturgeon, Acipenser oxyrinchus oxyrinchus, and shortnose sturgeon, A. brevirostrum, with notes on social behavior. Environmental Biology of Fishes 63, 137-150.

Kynard, B., Zhuang, P., Zhang, L., Zhang, T. and Zhang, Z. (2002) Ontogenetic behavior and migration of Volga River Russian sturgeon, Acipenser gueldenstaedtii, with a note on adaptive significance of body color. Environmental Biology of Fishes 65, 411-421.

Lelek, A. (1987) The Freshwater Fishes of Europe. Volume 9 , Threatened Fishes of Europe. AULA-Verlag, Wiesbaden.

Levin, A. (1997) The distribution and migration of sturgeons in the Caspian Sea. In: Sturgeon Stocks and Caviar Trade Workshop (Proceedings of the Sturgeon Stocks and Caviar Trade Workshop, Bonn, 9 October-10 October, 1995). V.J. Birstein, A. Bauer and A. KaiserPohlmann, eds. IUCN, Gland, Cambridge, Bonn, pp. 1320.

Logan, H.S., Johnston, W.E. and Doroshov, S.I. (1995) Economics of joint production of sturgeon (Acipenser transmontanus Richardson) and roe for caviar. Aquaculture 130, 299-316.

Luk'yanenko, V.I., Vasil'ev, A.S., Luk'yanenko, V.V. and Khabarov, M.V. (1999) On the increasing threat of extermination of the unique Caspian sturgeon populations and the sturgeon measures required to save them. Journal of Applied Ichthyology 15, 99-102.

Mayden, R.L. and Kuhajda, B.R. (1996) Systematics, taxonomy, and conservation status of the endangered Alabama sturgeon, Scaphirhynchus suttkusi Williams and Clemmer (Actinopterygii, Acipenserdae). Copeia 2, 241273.

Mayden, R.L. and Kuhajda, B.R. (1997a) Threatened species of the world: Scaphirhynchus albus (Forbes \& Richardson 1905) (Acipenseridae). In: Sturgeon Biodiversity and Conservation (eds V.J. Birstein, J.R. Waldman and W.E. Bemis). Kluwer Academic Publishers, Dordrecht, pp. 420-421.

Mayden, R.L. and Kuhajda, B.R. (1997b) Threatened species of the world: Scaphirhynchus suttkusi Williams \& Clemmer, 1991 (Acipenseridae). In: Sturgeon Biodiversity and Conservation (eds V.J. Birstein, J.R. Waldman and W.E. Bemis). Kluwer Academic Publishers, Dordrecht, pp. $418-419$.

McLeod, C., Hildebrand, L. and Radford, D. (1999) A synopsis of lake sturgeon management in Alberta, Canada. Journal of Applied Ichthyology 15, 173-179.

Mims, S.D. (2001) Aquaculture of paddlefish in the United States. Aquatic Living Resources 14, 391-398.

Mims, S.D. and Shelton, W.L. (1998) Induced meiotic gynogenesis in shovelnose sturgeon. Aquaculture International 6, 323-329.

Mims, S.D., Georgi, T.A. and Liu, C. (1993) The Chinese paddlefish, Psephurus gladius: biology, life history and potential for cultivation. World Aquaculture 25, 46-48.

Moghim, M. and Neilson, J.D. (1999) Imminent collapse of the Caspian Sea stellate sturgeon (Acipenser stellatus): evidence from the Iranian fishery. Ambio 28, 372-373. 
Mosher, T. (1999) Sturgeon and paddlefish sportsfishing in North America. In: Symposium on the Harvest, Trade and Conservation of North American Paddlefish and Sturgeon (Proceedings of the Symposium on the Harvest, Trade, and Conservation of North American Paddlefish and Sturgeon, Chattanooga, Tennessee, 7 May-8 May, 1998). D.F. Williamson, G.W. Benz and C.M. Hoover, eds. TRAFFIC North America/World Wildlife Fund, Washington, DC, pp. 51-66.

Moyle, P.B., Yoshiyama, R.M., Williams, J.E. and Wikramanayake, E.D. (1995) Green sturgeon, Acipenser medirostris Ayres. In: Fish Species of Special Concern in California). Department of Wildlife and Fisheries Biology, University of California, Davis, CA, pp. 26-35.

Musick, J.A., Harbin, M.M., Berkeley, S.A. et al. (2000) Marine, estuarine, and diadromous fish stocks at risk of extinction in North America (exclusive of Pacific Salmonids). Fisheries 25, 6-30.

Navodaru, I., Staras, M. and Cerni Sencu, I. (2001) The challenge of sustainable use of the Danube Delta Fisheries, Romania. Fisheries Management and Ecology 8, 323-332.

Nelson, T., English, K.K. and Gazey, E.J. (2002) The Status of White Sturgeon in the Lower Fraser River, British Columbia (unpublished report available from author at tnelson@lgl.com)

Nilo, P., Dumont, P. and Fortin, R. (1997) Climatic and hydrological determinants of year-class strength of St. Lawrence River lake sturgeon (Acipenser fulvescens). Canadian Journal of Fisheries and Aquatic Sciences 54, 774-780.

NMFS (1998a) Recovery plan for the shortnose sturgeon (Acipenser brevirostrum). Prepared by the Shortnose Recovery Team, Maryland National Marine Fisheries Service, Silver Springs, MD, 104 pp.

NMFS (1998b) Status Review of Atlantic Sturgeon (Acipenser oxyrinchus). National Marine Fisheries Service, Gloucester, MA.

Onders, R.J., Mims, S.D., Wang, C. and Pearson, W.D. (2001) Reservoir Ranching of Paddlefish. North American Journal of Aquaculture 63, 179-190.

Ong, T., Stabile, J., Wirgin, I. and Waldman, J.R. (1996) Genetic divergence between Acipenser oxyrinchus oxyrinchus and A. o. desotoi as addressed by mtDNA sequence analyses. Copeia 2, 464-469.

Parsley, M.J. and Beckman, L.G. (1994) White sturgeon spawning and rearing habitat in the lower Columbia River. North American Journal of Fisheries Management 14, 812-827.

Parsley, M.J., Beckman, L.G. and McCabe, G.T. (1993) Spawning and rearing habitat use by white sturgeons in the Columbia River downstream from McNary Dam. Transactions of the American Fisheries Society 122, 217227.

Parsley, M., Anders, P.J., Miller, A.J., Beckman, L.G. and McCabe, G.T. (2002) Recovery of white sturgeon populations through natural production: understanding the influence of abiotic and biotic factors on spawning and subsequent recruitment. In: Biology, Management and Protection of North American Sturgeon (eds W., Van Winkle, P.J., Anders, D.H., Secor and D.A., Dixon). American Fisheries Society, Bethesda, MD, pp. 55-66.

Pearce, F. (2003) Miscalculation could mean the end of caviar. New Scientist, September 20, 2003, 179, 6-7.

Peterson, D.L., Bain, M.B. and Haley, N. (2000) Evidence of Declining Recruitment of Atlantic Sturgeon in the Hudson River. North American Journal of Fisheries Management 20, 231-238.

Peterson, D., Gunderman, B. and Vecsei, P. (2002) Lake sturgeon of the Manistee River: a current assessment of spawning stock size, age and growth. In: Biology, Management and Protection of North American Sturgeon (eds W. Van Winkle, P.J. Anders, D.H. Secor and D.A. Dixon). American Fisheries Society, Bethesda, MD, pp. 175-182.

Petr, T. and Mitrofanov, V.P. (1998) The impact on fish stocks of river regulation in Central Asia and Kazakhstan. Lakes \& Reservoirs: Research and Management 3, 143-164.

Pikitch, E.K., Santora, C., Babcock, E.A. et al. (2004a) Ecosystem-based fishery management. Science $\mathbf{3 0 5}$, 346-347.

Pikitch, E.K., Doukakis, P. and Santora, C. (2004b) Caspian sturgeons and captive caviar production: understanding conservation benefits. Fish Farmer 27, 31-33.

Quattro, J.M., Greig, T.W., Coykendall, D.K., Bowen, B.W. and Baldwin, J.D. (2002) Genetic issues in aquatic species management: the shortnose sturgeon (Acipenser brevirostrum) in the southeastern United States. Conservation Genetics 3, 155-166.

Quist, M.C., Guy, C.S., Pegg, M.A., Braaten, P.J., Pierce, C.L. and Travnichek, V.H. (2002) Potential influence of harvest on shovelnose sturgeon populations in the Missouri river system. North American Journal of Fisheries Management 22, 537-549.

Raspopov, V.M. (1993a) Age structure and population dynamics of the beluga, Huso huso, migrating into the Volga River. Journal of Ichthyology 33, 105-112.

Raspopov, V.M. (1993b) Growth rate of Caspian Sea beluga. Journal of Ichthyology 33, 72-84.

Raymakers, C. (2002) International trade in sturgeon and paddlefish species - the effect of CITES listing. International Review of Hydrobiology 87, 525-537.

Raymakers, C. and Hoover, C. (2002) Acipenseriformes: CITES implementation from Range States to consumer countries. Journal of Applied Ichthyology 18, 629-638.

Rieman, B.E. and Beamesderfer, R.C. (1990) White sturgeon in the lower Columbia River: is the stock overexploited. North American Journal of Fisheries Management 10, 388-396. 
Rochard, E., Castelnaud, G. and Lepage, M. (1990) Sturgeons (Pisces: Acipenseridae): threats and prospects. Journal of Fish Biology 37 (Suppl. A), 123-132.

Root, K. (2002) Evaluating risks for threatened aquatic species: the shortnose sturgeon in the Connecticut River. In: Biology, Management and Protection of North American Sturgeon (eds W. Van Winkle, P.J. Anders, D.H. Secor and D.A. Dixon). American Fisheries Society, Bethesda, MD, pp. 45-54.

Rosenthal, H. and Hilge, V. (2000) Aquaculture production and environmental regulations in Germany. Journal of Ichthyology 16, 163-166.

Ruban, G.I. (1997) Species structure, contemporary distribution and status of the Siberian sturgeon, Acipenser baerii. In: Sturgeon Biodiversity and Conservation (eds V.J. Birstein, J.R. Waldman and W.E. Bemis). Kluwer Academic Publishers, Dordrecht, pp. 221-230.

Ruban, G.I. (1998) On the species structure of the Siberian sturgeon Acipenser baerii Brandt (Acipenseridae). Journal of Ichthyology 38, 345-365).

Ruban, G.I. and Akimova, N.V. (2001) Reproductive system condition and the reason for decreased abundance of Siberian sturgeon Acipenser baerii from the $\mathrm{Ob}$ River. Journal of Ichthyology 41, 177-181.

Runstrom, A.L., Vondracek, B. and Jennings, C.A. (2001) Population statistics for paddlefish in the Wisconsin River. Transactions of the American Fisheries Society 130 , 546-556.

Salnikov, V., Birstein, V.J. and Mayden, R.L. (1996) The contemporary status of the two Amu-Darya River shovelnose sturgeons, Pseudoscpahirhynchus kaufmanni and P. hermanni. Sturgeon Quarterly 4, 10-14.

Scarnecchia, D.L., Gengerke, T.W. and Moen, C.L. (1989) Rationale for a harvest slot limit for paddlefish in the Upper Mississippi River. North American Journal of Fisheries Management 9, 477-487.

Schram, S.T., Lindgren, J. and Evrard, L.M. (1999) Reintroduction of Lake Sturgeon in the St. Louis River, Western Lake Superior. North American Journal of Fisheries Management 19, 815-823.

Secor, D.H. (2002) Atlantic sturgeon fisheries and stock abundances during the late nineteenth century. In: Biology, Management and Protection of North American Sturgeon (eds W. Van Winkle, P.J. Anders, D.H. Secor and D.A. Dixon). American Fisheries Society, Bethesda, MD, pp. 89-100.

Secor, D.H. and Waldman, J.R. (1999) Historical Abundance of Delaware Bay Atlantic sturgeon and potential rate of recovery. American Fisheries Society Symposium 23, 203-216.

Secor, D.H., Arefiev, V., Nikolaev, A. and Sharov, A. (2000) Restoration of sturgeons: lessons from the Caspian Sea Sturgeon ranching programme. Fish and Fisheries 1, 215-230.

Secor, D.H., Anders, P.J., Van Winkle, W. and Dixon, D.A. (2002) Can we study sturgeons to extinction? What we do and don't know about the conservation of North American sturgeon. In: Biology, Management and Protection of North American Sturgeon (eds W. Van Winkle, P.J. Anders, D.H. Secor and D.A. Dixon). American Fisheries Society, Bethesda, MD, pp. 3-12.

Shagaeva, V.G., Nikol'skaya, M.P., Akimova, N.V., Markov, K.P. and Nikol'skaya, N.G. (1993) A study of the early ontogeny of Volga sturgeon (Acipenseridae) subjected to human activity. Journal of Ichthyology 33, 1993.

Smith, T.I.J. and Clugston, J.P. (1997) Status and management of Atlantic sturgeon, Acipenser oxyrinchus, in North America. In: Sturgeon Biodiversity and Conservation (eds V.J. Birstein, J.R. Waldman and W.E. Bemis). Kluwer Academic Publishers, Dordrecht, pp. 335-346. Smith, T.I.J., Collins, M.R., Post, W.C. and McCord, J.W. (2002a) Stock enhancement of shortnose sturgeons: a case study. In: Biology, Management and Protection of North American Sturgeon (eds W. Van Winkle, P.J. Anders, D.H. Secor and D.A. Dixon). American Fisheries Society, Bethesda, MD, pp. 31-44.

Smith, T.I.J., McCord, J.W., Collins, M.R. and Post, W.C. (2002b) Occurrence of stocked shortnose sturgeon Acipenser brevirostrum in non-target rivers. Journal of Applied Ichthyology 18, 470-474.

Sokolov, L.I. and Tsepkin, E.A. (1996) Sturgeons from the Azov-Black Seas and Caspian basins: a historical review. Journal of Ichthyology 36, 11-23.

Solovov, V. (1997) Present status of the population of Acipenser baerii in the upper reaches of the Ob. Journal of Ichthyology 37, 41-47.

Solovov, L.I. and Vasila'v, V.P. (1989) Acipenser baerii Brandt, 1896. In: The Freshwater Fishes of Europe, Vol. I/ II General Introduction of Fishes, Acipenseriformes (ed. J. Holcik). AULA-Verlag, Wiesbaden, pp. 263-284.

Speer, L., Lauck, L., Pikitch, E., Boa, S., Dropkin, L. and Spruill, V. (2000) Roe to Ruin: The Decline of Sturgeon in the Caspian Sea and the Road to Recovery. Wildlife Conservation Society, Natural Resource Defense Council, SeaWeb, (http://www.caviaremptor.org/report.html), 26 pp.

St. Pierre, R. (1999) restoration of Atlantic sturgeon in the northeastern USA with special emphasis on culture and restocking. Journal of Applied Ichthyology 15, 180-182.

Stabile, J., Waldman, J.R., Parauka, F. and Wirgin, I. (1996) Stock structure and homing fidelity in Gulf of Mexico sturgeon (Acipenser oxyrinchus desotoi) based on restriction fragment length polymorphism and sequence analyses of mitochondrial DNA. Genetics 144, 767-775.

Stone, R. (2002) Caspian ecology teeters on the brink. Science 295, 430-433.

Taylor, S. (1997) The historical development of the caviar trade and the caviar industry. In: International Symposium on Sturgeons (Proceedings of the International Symposium on Sturgeons, Moscow, 6 September-11 September, 1993). A.D. Gershanovich and T.I.J. Smith, eds. VNIRO Publishing, Moscow, pp. 45-54. 
Thomas, M. and Haas, R.C. (2002) Abundance, age structure, and spatial distribution of lake sturgeon, Acipenser fulvescens, in the St Clair System. Journal of Applied Ichthyology 18, 495-501.

Threader, R.W. and Brousseau, C.S. (1986) Biology and management of the Lake sturgeon in the Moose River, Ontario. North American Journal of Fisheries Management 6, 383-390.

Thuemler, T. (1997) Lake sturgeon management in the Menominee River, a Wisconsin-Michigan boundary water. In: Sturgeon Biodiversity and Conservation (eds V.J. Birstein, J.R. Waldman and W.E. Bemis). Kluwer Academic Publishers, Dordrecht, pp. 311-317.

Todd, R. (1999) Sturgeon and paddlefish commercial fishery in North America. In: Symposium on the Harvest, Trade and Conservation of North American Paddlefish and Sturgeon (Proceedings of the Symposium on the Harvest, Trade, and Conservation of North American Paddlefish and Sturgeon, Chattanooga, Tennessee, 7 May-8 May, 1998). D.F., Williamson, G.W., Benz and C.M., Hoover, eds. TRAFFIC North America/World Wildlife Fund, Washington, DC, pp. 42-50.

Tranah, G., Kincaid, H.L., Krueger, C.C., Campton, D.E. and May, B. (2001) Reproductive isolation in sympatric populations of pallid and shovelnose sturgeon. North American Journal of Fisheries Management 21, 367-373.

Trencia, G., Verreault, G., Georges, S. and Pettigrew, P. (2002) Atlantic sturgeon (Acipenser oxyrinchus oxyrinchus) fishery management in Quebec, Canada, between 1994 and 2000. Journal of Applied Ichthyology 18, 455462.

Tsvetneko, Y.B. (1993) The effectiveness and genetic consequences of the introduction of the stellate sturgeon, Acipenser stellatus, into the Azov basin from the Caspian Sea. Journal of Ichthyology 33, 1-10.

Vaisman, A. and Raymakers, C. (2001) Legal status of sturgeon fisheries in the Russian Federation. TRAFFIC Bulletin 19, 33-44.

Van Winkle, W., Anders, P.J., Secor, D.H., Dixon, D.A. (eds) (2002) Biology, Management and Protection of North American Sturgeon, Symposium 28. American Fisheries Society, Bethesda, MD.

Vasil'ev, V. (1999) Polyplodization by reticular speciation in Acipenseriform evolution: a working hypothesis. Journal of Applied Ichthyology 15, 29-31.

Vecsei, P., Artyukhin, E. and Peterson, D. (2002) Threatened fishes of the world: Acipenser nudiventris Lovetsky, 1828 (Acipenseridae). Environmental Biology of Fishes 65, 455-456.

Vlasenko, A.D., Pavlov, A.V. and Vasil'ev, V.P. (1989) Acipenser persicus Borodin, 1897. In: The Freshwater Fishes of Europe. Vol. 1. Pt. II. General Introduction to Fishes. Acipenseriformes (ed. J. Holcik). AULA-Verlag, Wiesbaden, pp. 345-366.
Waldman, J.R. and Wirgin, I.I. (1998) Status and restoration options for Atlantic sturgeon in North America. Conservation Biology 12, 631-638.

Waldman, J.R., Nolan, K., Hart, J. and Wirgin, I.I. (1996) Genetic differentiation of three key anadromous fish populations of the Hudson River. Estuaries 19, 759-768.

Waldman, J., Grunwald, C., Stabile, J. and Wirgin, I.I. (2002) Impacts of life history and biogeography on the genetic stock structure of Atlantic sturgeon Acipenser oxyrinchus oxyrinchus, Gulf sturgeon A. oxyrinchus desotoi, and shortnose sturgeon A. brevirostrum. Journal of Applied Ichthyology 18, 509-518.

Wei, Q., Ke, F., Zhang, J., Zhuang, P., Luo, J., Zhou, R. and Yang, W. (1997) Biology, fisheries and conservation of sturgeons and paddlefish in China. In: Sturgeon Biodiversity and Conservation (eds V.J. Birstein, J.R. Waldman and W.E. Bemis). Kluwer Academic Publishers, Dordrecht, pp. 241-255.

Wei, Q., He, J., Yang, D., Zheng, W. and Li, L. (2004) Status of sturgeon aquaculture and sturgeon trade in China: a review based on two recent nationwide surveys. Journal of Applied Ichthyology 20, 321-332.

Williamson, D.F. (2003) Caviar and Conservation: Status, Management and Trade of North American Sturgeon and Paddlefish. TRAFFIC North America, Washington DC, 240 pp.

Williot, P., Rochard, E., Castlenaud, G., Rouault, T., Brun, R., Lepage, M. and Elie, P. (1997) Biological characteristics of European Atlantic sturgeon, Acipenser sturio, as the basis for a restoration program in France. In: Sturgeon Biodiversity and Conservation (eds V.J. Birstein, J.R. Waldman and W.E. Bemis). Kluwer Academic Publishers, Dordrecht, pp. 359-370.

Williot, P., Sabeau, L., Gessner, J., Arlati, G., Bronzi, P., Gulyas, T. and Berni, P. (2001) Sturgeon farming in Western Europe: recent developments and perspectives. Aquatic Living Resources 14, 367-374.

Wirgin, I., Waldman, J.R., Rosko, J., Gross, R., Collins, M.R., Rogers, S.G. and Stabile, J. (2000) Genetic structure of Atlantic sturgeon populations based on $\mathrm{mt}$ DNA control region sequences. Transactions of the American Fisheries Society 129, 476-486.

Wirgin, I., Waldman, J.R., Stabile, J., Lubinski, B. and King, T. (2002) Comparison of mitochondrial DNA control region sequence and microsatellite DNA analyses in estimating population structure and gene flow rates in Atlantic sturgeon Acipenser oxyrinchus. Journal of Applied Ichthyology 18, 313-319.

Zaitsev, Y.P. (1993) Impact of eutrophication on the Black Sea fauna. In: Studies and Reviews, Vol. 64. General Fisheries Council for the Mediterranean, FAO, Rome, 59-86.

Zholdasova, I. (1997) Sturgeons and the Aral Sea catastrophe. In: Sturgeon Biodiversity and Conservation (eds V.J. Birstein, J.R. Waldman and W.E. Bemis). Kluwer Academic Publishers, Dordrecht, pp. 373-380. 
Zhuang, P., Ke, F., Wei, Q., He, X. and Cen, Y. (1997) Biology, and life history of Dabry's sturgeon, Acipenser dabryanus, in the Yangtze River. In: Sturgeon Biodiversity and Conservation (eds V.J. Birstein, J.R. Waldman and W.E. Bemis). Kluwer Academic Publishers, Dordrecht, pp. 257-264.
Zhuang, P., Kynard, B., Zhang, L., Zhang, T., Zhang, Z. and Li, D. (2002) Overview of biology and aquaculture of Amur sturgeon (Acipenser schrenckii) in China. Journal of Ichthyology 18, 659-665. 